\title{
Oil composition of high fat diet affects differently metabolic inflammation in connection with endotoxin receptors in mice
}

Fabienne Laugerette, ${ }^{\mathrm{a}, \mathrm{b}}$ Jean-Pierre Furet, ${ }^{\mathrm{c}}$ Cyrille Debard, ${ }^{\mathrm{d}}$ Patricia Daira, ${ }^{\mathrm{b}}$ Emmanuelle Loizon, ${ }^{\mathrm{d}}$ Alain Géloën, ${ }^{\mathrm{b}}$ Christophe Soulage, ${ }^{\mathrm{b}}$ Claire Simonet, ${ }^{\mathrm{a}}$ Jennifer LefilsLacourtablaise, ${ }^{\mathrm{b}}$ Nathalie Bernoud-Hubac, ${ }^{\mathrm{b}}$ Jacques Bodennec, ${ }^{\mathrm{e}}$ Noël Peretti, ${ }^{\text {e,f }}$ Hubert Vidal, ${ }^{\text {,ff }}$ and Marie-Caroline Michalski ${ }^{\mathrm{a}, \mathrm{b}, \mathrm{f}, *}$

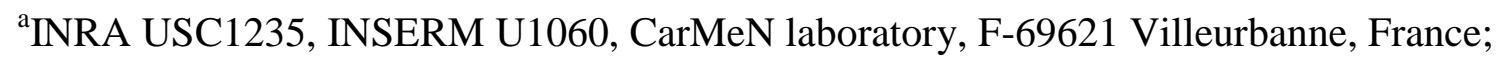
${ }^{\mathrm{b}}$ INSA-Lyon, IMBL, Villeurbanne, France; ${ }^{\mathrm{I} I N R A, ~ M I C A L I S ~ I n s t i t u t e, ~ J o u y-e n-J o s a s, ~}$ France; ' ${ }^{\mathrm{I}}$ INSERM U1060, CarMeN laboratory, F-69921 Oullins, France; 'Lyon University, Univ Lyon-1, Villeurbanne, France; ${ }^{\mathrm{f}}$ CRNH Rhône-Alpes, CENS, F-69921 Oullins, France.

*Correspondence to: MC Michalski, PhD, INRA USC1235, INSERM U1060,

Cardiovascular Metabolism diabetes and Nutrition Laboratory, CarMeN, Bâtiment IMBL, INSA-Lyon, 11 avenue Jean Capelle, 69621 VILLEURBANNE cedex, France Tel : +33472438112 - Fax : +33472438524

E-mail: marie-caroline.michalski@insa-lyon.fr

Running title: Oil composition and endotoxin receptors.

Abbreviations used: LPS (lipopolysaccharides), FA (fatty acids), SFA (saturated fatty acids), PUFA (polyunsaturated fatty acids), PL (phospholipids), WAT (white adipose tissue), MF (milk fat), P (palm oil), R (rapeseed oil), S (sunflower oil). 


\begin{abstract}
Low-grade inflammation observed in obesity is a risk factor for cardiovascular disease. Recent studies revealed that this would be linked to gut-derived endotoxemia during fat digestion in high fat diets, but nothing is known about the effect of lipid composition. The study was designed to test the impact of oil composition of high fat diets on endotoxin metabolism and inflammation in mice. C57/B16 mice were fed for 8 weeks with chow or isocaloric isolipidic diets enriched with oils differing in fatty acid composition: milk fat, palm oil, rapeseed oil or sunflower oil. In vitro, adipocytes (3T3-L1) were stimulated or not with lipopolysaccharide (LPS, endotoxin) and incubated with different fatty acids. In mice, the palm group presented the highest level of IL-6 in plasma $(P<0.01)$ together with the highest expression in adipose tissue of IL-1 $\beta$ and of LPS-sensing TLR4 and CD14 $(P<0.05)$. The higher inflammation in palm group was correlated with a greater ratio of LPS-Binding Protein $(\mathrm{LBP}) / \mathrm{sCD} 14$ in plasma $(P<0.05)$. Rapeseed group resulted in higher sCD14 than palm group, associated with lower inflammation both in plasma and adipose tissue despite higher plasma endotoxemia. Taken together, our results reveal that the palm oil-based diet resulted in the most active transport of LPS toward tissues via high LBP and low sCD14 and the greatest inflammatory outcomes. In contrast, rapeseed-oil based diet seemed to result in an endotoxin metabolism driven towards less inflammatory pathways. This shows that dietary fat composition can contribute to modulate the onset of low-grade inflammation through the quality of endotoxin receptors.
\end{abstract}

Keywords: Fatty acid; endotoxin; sCD14; LBP; nutrition. 


\section{INTRODUCTION}

Obesity results from complex interactions between environmental and genetic factors and is associated with a cluster of metabolic disorders such as hyperlipemia and diabetes and constitute risk factors for cardiovascular diseases (34). Among environmental factors, a fatenriched diet, excessive calorie intake and a sedentary lifestyle increase this occurrence. Obesity and associated metabolic disorders are also characterized by a chronic or so-called "low-grade" inflammation that is a risk factor for metabolic diseases (32). Along with muscle and liver, the white adipose tissue (WAT) is an important tissue involved in several systemic processes such as glucose tolerance and inflammatory response via secretion of adipokines (73). Several distinct inflammatory pathways are involved in the secretion of proinflammatory cytokines and chemokines, such as interleukin-6 (IL-6), interleukin-1 $\beta$ (IL-1 $\beta$ ) and monocyte chemotactic protein-1 (MCP-1), by WAT (57). However, while the effects of inflammatory reactions on lipid metabolism and insulin resistance are known, the mechanisms contributing to the generation of low-grade inflammation remain to be elucidated.

In this respect, recent studies have shown that rodents fed a high-fat diet display alterations of gut microbiota that increase intestinal permeability (10) and gut inflammation (6). Previous data in humans and rodents revealed that $\sim 90 \%$ of a normal gut microbiota is made of the Bacteroidetes and Firmicutes phyla, while obesity is linked to changes in their proportions (21, 31, 44, 80). More recently, a link was revealed between high-fat diet, inflammation and the occurrence in plasma of pro-inflammatory products of Gram-negative bacteria of gut microbiota, namely lipopolysaccharides (LPS) so-called "endotoxins" $(9,10)$. The endotoxin metabolic pathway then includes the binding of LPS to LPS Binding Protein (LBP) and its subsequent transfer to the receptor CD14. Two forms of CD14 have been characterized: a membrane-bound glycoprotein (mCD14) and a circulating soluble form (sCD14) (29). LBP and sCD14 levels can be considered as relevant markers of endotoxins in plasma (30). In this respect, given the long half-lives of sCD14 and LBP (24-48 hours) compared to endotoxin 
(from $<8$ min in mice to a maximum of 3 hours in humans), sCD14 and plasma LBP seem to reflect long-term exposure to endotoxin rather than the measurement of endotoxemia itself $(49,60)$, which is more reliable to measure transient kinetics of endotoxin absorption $(18,39)$. Regarding the metabolic impact of these LPS transporters and receptors, LBP-bound LPS initiates inflammation via toll-like receptor-4 (TLR4) associated with mCD14 and induces the secretion of pro-inflammatory cytokines such as IL-6 that is involved in inflammation (67). In septic shock high amounts of LBP inhibit LPS activity but low amounts of LBP in regular metabolic state are reported to increase LPS proinflammatory activity (38). Noticeably, sCD14 is reported to have suppressing effects on endotoxin activity by driving detoxification by HDL (70). Interestingly however, fatty acids (FA) also bind TLR4 to induce proinflammatory cytokine expression in macrophages and adipocytes (66).

Recent studies including ours showed that metabolic endotoxemia could be generated by gut LPS absorption during digestion of a high lipid load $(4,9,18,27,39)$. But none of these studies took into account the numerous dietary fat sources in Western diets and their FA profile that is suspected to affect the development of inflammatory response (5). Therefore, the impact of oil fatty acid composition in Western-type diets on endotoxemia, LPS transporters and receptors and the onset of inflammatory outcomes deserves to be elucidated. Moreover, high fat diet studies in rodents used up to date regimen with $>60 \%$ of energy as lard and devoid of carbohydrates $(9,11)$; therefore, the mechanisms associating dietary fat with endotoxin metabolism and inflammation deserves to be studied in more equilibrated fatrich regimen.

The aim of this study was thus to compare the effects of oils differing in fatty acid composition on endotoxin metabolism and inflammation in plasma and adipose tissue in the dynamic phase of weight gain and inflammation onset. Therefore, we tested animal diets based on chow enriched with different fat sources, i.e., milk fat, palm oil, rapeseed oil and 
sunflower oil. Because acute gavage studies had already been performed in previous studies $(9,18,27,39)$, and short-duration diets can be unsufficient to observe inflammation, we chose to use a sufficient duration of 8 weeks to be able to induce the onset of metabolic inflammation that we aimed to compare with LPS receptors and endotoxemia.

\section{MATERIALS AND METHODS}

Specific non-pyrogenic material. Great care was taken to avoid contamination with exogenous LPS during experiments. Only single-use non pyrogenic material was used: PS Becton Dickinson tubes, Axygen tubes (VWR, France), pyrogen-free pipette tips (Biogenic, Perols, France).

Ethics statement. Experiments were carried out according to the guidelines laid down by the French Ministère de 1'Agriculture ( $\mathrm{N}^{\circ} 87-848$ completed by $\left.\mathrm{N}^{\circ} 2001-464\right)$ and E.U. Council Directive for the Care and Use of Laboratory Animals ( $N^{\circ}$ 86/609). CS ( $\mathrm{n}^{\circ}$ 69266257) and AG ( $n^{\circ}$ 69266332) hold a license to experiment on living vertebrates issued by the French Ministry of Agriculture and Veterinary Service Department. French law on animal experimentation does not require however, for authorized people (with a licence number), the systematic review of animal research protocols by an ethics committee or review board institution.

Animals and diets. Male C57B16/J mice (6 weeks, $18 \mathrm{~g}$ ), were purchased from Harlan (Gannat, France) and kept at $24 \pm 1{ }^{\circ} \mathrm{C}$ on a 12/12 h light cycle (light on from 06:00h to 18:00h) with a free access to food and tap water. Animals were housed at 4 per cage and adapted to the laboratory conditions for one week before beginning the experiment. Fat-rich diets were prepared by SAFE (Augy, France) and contained $22.4 \%$ of lipids (Table 1). Mice were randomly divided into 5 groups ( $n=8$ per group) fed one of the 5 following diets during 
8 weeks: a milk fat-enriched diet (MF), a palm oil-enriched diet (P), a rapeseed oil-enriched $\operatorname{diet}(\mathrm{R})$, a sunflower oil-enriched $\operatorname{diet}(\mathrm{S})$; a normal chow diet $(\mathrm{Ch})$ was used as low-fat control (A04, SAFE, Augy, France). Fat-rich diets were thus especially designed to differ in oil composition only (76) and oils were chosen among the major dietary fats consumed worldwide (17). Importantly, diets were manufactured using fats and oils for human consumption. Rapeseed and sunflower oil were from Lesieur (France), Palm oil was from SIO (Saint Laurent Blangy, France) and anhydrous milk fat was from Lactalis R\&D (Retiers, France). Oils were therefore certified to be devoid of Gram negative bacteria; they were found non-pyrogenic using the LAL assay (no detectable endotoxemia). Moreover, diets produced by manufacturer (SAFE) passed all microbiological quality checks.

Food intake was measured twice a week for 8 weeks and average food intake per day subsequently calculated. After 8 weeks under diet, mice were randomly sacrificed non-fasted during 4 days ( 2 mice per group per day) between 09:00h and 12:00h by intraperitoneal injection of pentobarbital. Blood was collected by cardiac puncture under pyrogen-free conditions on heparin-containing tubes. Plasma was obtained by centrifugation $(8000 \mathrm{~g}, 10$ min), frozen in liquid nitrogen and stored at $-80^{\circ} \mathrm{C}$ until analysis. Small intestine mucosa, caecum contents, liver and white adipose tissue (WAT) corresponding to epididymal tissue, were collected, frozen in liquid nitrogen and stored at $-80^{\circ} \mathrm{C}$.

3T3-L1 cell culture and treatment. 3T3-L1 cells were obtained from the American Type Culture Collection (ATCC, Manassas, VA, USA) and cultured at $37^{\circ} \mathrm{C}$ under $5 \% \mathrm{CO}_{2}$ in Dulbecco's modified Eagle's medium (DMEM, Sigma), to which 10\% fetal calf serum (BioWest), 4 mM L-Glutamine and antibiotics (Sigma) were added. Cell differentiation was performed in DMEM containing $5 \mu \mathrm{g} / \mathrm{mL}$ insulin (Actrapid 100UI/mL, Novo-Nordisk), 0.5 mM 3-isobutyl-1-methyl-xanthine (Sigma), $0.25 \mu \mathrm{mol} / \mathrm{L}$ dexamethasone (Sigma) and 10 
$\mu \mathrm{mol} / \mathrm{L}$ rosiglitazone (Molekula) for $48 \mathrm{~h}$. On the $10^{\text {th }}$ day after differentiation, cells were harvested $4 \mathrm{~h}$ before treatment. In our experiment, the first set of cells ( $n=6$ per treatment) was treated with DMEM containing $5 \mu \mathrm{g} / \mathrm{mL}$ insulin and one of the following fatty acids: myristic, palmitic, linoleic and linolenic acids (Sigma) at $100 \mu \mathrm{mol} / \mathrm{L}$ conjugated to $50 \mu \mathrm{mol}$ bovine serum albumin (Sigma). The second set of cells ( $n=6$ per treatment) received the same fatty acids with $0.1 \mu \mathrm{g} / \mathrm{mL}$ of LPS from E. coli O55:B5 (Sigma) (24). Control cells were incubated with DMEM with or without $0.1 \mu \mathrm{g} / \mathrm{mL}$ of LPS. Treatments lasted $24 \mathrm{~h}$. At the end of experiment, cells and medium were taken and stored at $-80^{\circ} \mathrm{C}$.

Limulus amoebocyte lysate (LAL) assays. Plasma endotoxemia (endotoxin unit per mL: EU/mL) was determined by using the limulus amoebocyte lysate (LAL) assay in kinetic chromogenic conditions (Biogenic, Pérols, France) as previously described (39). Briefly, plasma sample was thawed and diluted $1 / 40$ in pyrogen-free water (Biogenic), heated at $70^{\circ} \mathrm{C}$ for $10 \mathrm{~min}$, subjected to an ultrasonic bath for $5 \mathrm{~min}$ and to a $1 \mathrm{~min}$ vortex. One hundred microliters of sample was combined with $100 \mu \mathrm{LAL}$ reagent (Chromolal, Biogenic) in triplicate in pyrogen-free 96-well plates (Biogenic). For each sample, a spiked control at 0.45 $\mathrm{EU} / \mathrm{mL}$ was performed to check that no significant inhibition or activation occurred. According to the FDA procedure, endotoxemia measurement is considered valid in these conditions if spike recovery is in the range $50-200 \%$ (75), that is, $0.225-0.9 \mathrm{EU} / \mathrm{mL}$ greater than sample endotoxemia. In this study, spike recovery was in the range $95-124 \%$ (no significant differences among groups). Moreover, standard curve presented always regression coefficient of $\sim 0.99$ and the non-pyrogenicity of water was systematically checked. Data were analysed for endotoxemia calculation using the Softmax Pro software (Biogenic). 
sCD14, LBP, IL-6, MCP-1 measurements. IL-6, MCP-1 (Clinisciences), sCD14 and LBP (Enzo Life Sciences) were assayed by ELISA kit according to the manufacturer's instructions. For 3T3-L1, IL-6 concentration of media was measured using mouse-specific ELISA kit (Pierce Endogen).

Plasma triacylglycerol and non-esterified fatty acids (NEFA) measurements. Plasma triacylglycerols (TAG) were measured with the triglyceride PAP kit (Biomérieux, France) using culture plates (Corning) as described previously (52). Real plasma TAG concentration was calculated by subtracting the free glycerol in plasma measured with the glycerol UVmethod (R-Biopharm/Boehringer, Mannheim, Germany) (52). Plasma NEFA were measured using NEFA-HR R2 Set kit (Wako Chemicals, Neuss, Germany).

Western Blots. WAT were lysed in RIPA buffer (1\% TritonX-100, $50 \mathrm{mM}$ Tris, pH7.5, 150 $\mathrm{mM} \mathrm{NaCl}, 5 \mathrm{mM}$ EDTA, $0.5 \mathrm{mM} \mathrm{Na}_{3} \mathrm{VO}_{4}, 50 \mathrm{mM} \mathrm{NaF}, 10 \mathrm{mg} / \mathrm{L}$ aprotinin, $10 \mathrm{mg} / \mathrm{L}$ leupeptin, $10 \mathrm{mg} / \mathrm{L}$ pepstatin and $1 \mathrm{mM}$ PMSF). Fifty $\mu \mathrm{g}$ of proteins (8) were subjected to Western-blotting by separation using SDS-PAGE (10\%) and transfer to polyvinylidine fluoride membrane. Membranes were blotted for TLR4 and tubulin (Santa Cruz Biotechnologies) using specific antibodies combined with HRP-conjugated anti-rabbit IgG antibody. Blots were developed using the ECL chemiluminescence method (GE Healthcare, Buckinghamshire, UK). Quantification was performed by densitometric analysis of specific bands on immunoblots using Quantity One software (BioRad).

Quantitative PCR analysis of caecal microbiota. Total bacteria DNA was extracted from $0.2 \mathrm{~g}$ of animal caecal material ( $\mathrm{n}=3$ per group) using the G'NOME kit (BIO 101, La Jolla, CA) 
with modifications as previously described (22). After the final precipitation, DNA was resuspended in $150 \mathrm{ml}$ of TE buffer and stored at $-20^{\circ} \mathrm{C}$ prior to further analysis.

The primers and probes used in this study, performed using an ABI 7000 Sequence Detection System with software version 1.2.3 (Applied Biosystems), were previously described (22). TaqMan qPCR was adapted to quantify the total bacteria population in addition to the dominant (>1\% of fecal bacteria) bacterial group; Clostridium leptum (C. leptum), Blautia (Clostridium) coccoides (Bl. coccoides), Bacteroides/Prevotella and Bifidobacterium genus. Real-time qPCR using SYBR Green was performed for the subdominant bacterial group Lactobacillus/Leuconostoc/Pediococcus group and for the species Escherichia coli (E. coli). The TaqMan probes were synthesized by Applied Biosystems Applera-France (Courtaboeuf, France) and Primers were purchased from MWG (MWG-Biotech AG, Ebersberg, Germany). Real-time qPCR was performed using an ABI 7000 Sequence Detection System with software version 1.2.3 (Applied Biosystems, Foster City, CA). Amplification and detection were carried out in 96-well plates with TaqMan Universal PCR 2× MasterMix (Applied Biosystems) or with SYBR Green PCR 2× Master Mix (Applied Biosystems). Each reaction was run in duplicate in a final volume of $25 \mu \mathrm{l}$ with $0.20 \mu \mathrm{mol} / \mathrm{l}$ final concentration of each primer, $0.25 \mu \mathrm{mol} / \mathrm{l}$ final concentration of each probe, and $10 \mu \mathrm{l}$ of appropriately diluted DNA samples. Amplifications were carried out using the following ramping profile: one cycle at $95^{\circ} \mathrm{C}$ for $10 \mathrm{~min}$, followed by 40 cycles of $95^{\circ} \mathrm{C}$ for $30 \mathrm{~s}, 60^{\circ} \mathrm{C}$ for $1 \mathrm{~min}$. The total numbers of bacteria were inferred from averaged standard curves as described (46).

Quantitative PCR analysis of WAT. Total RNA were extracted from $50 \mathrm{mg}$ of white adipose tissue with TRIzol (Invitrogen, Eragny, France). First-strand cDNAs were synthesized from 1 $\mu \mathrm{g}$ of total RNA in the presence of 100 units of Superscript II (Invitrogen) using a mixture of random hexamers and oligo (dT) primers (Promega, Charbonnières, France). Real-time PCR 
assays were performed using a Rotor-Gene Q (Qiagen, France). TATA-box Binding Protein (TBP) mRNA level was used to normalize the data. The PCR primers were the following: TLR4 (forward: AGTGGCTGGATTATCCAGG; reverse: TCCACAGCCACCAGATTCTC); IL-6 (forward: AGTTGCCTTCTTGGGACTGAT; reverse: $\quad$ TCCACGATTTCCCAGAGAAC); CD14 (forward: TCAGCTAAACTCGCTCAATC; reverse: TCCAGCCTGTTGTAACTGAG); CD68 (forward: AGCATAGTTCTTTCTCCAGC; reverse: ATGATGAGAGGCAGCAAGAG); IL$1 \beta$ (forward: ACTGTTCCTGAACTCAACTG; reverse: CTTGTTGATGTGCTGCTGCG); TBP (forward: TGGTGTGCACAGGAGCCAAG; reverse: TTCACATCACAGCTCCCCAC).

Immunogold labeling for transmission electron microscopy. A fraction of jejunum was placed against freshly ionized Fomvar-carbon coated $200 \mu \mathrm{m}$ mesh nickel grids suspension during 2 minutes. To avoid false-positives, non-specific sites were blocked with $1 \%$ BSA in $50 \mathrm{mM}$ Tris- $\mathrm{HCl}, \mathrm{pH} 7.4$ for $10 \mathrm{~min}$ at $\mathrm{RT}$. The jejunal pieces were then incubated with a $1 / 30$ dilution of mouse monoclonal antibody anti-Lipopolysaccharide core (E. coli and Enterobacteria, Hycult Biotechnology, Netherland) in wet chamber, $2 \mathrm{~h}$ at $4^{\circ} \mathrm{C}$. Grids with suspension were successively washed once in $50 \mathrm{mM}$ Tris- $\mathrm{HCl}, \mathrm{pH} 7.4$ and $\mathrm{pH} 8.2$ at RT. Then, they were incubated in a wet chamber for $45 \mathrm{~min}$ at RT in $1 \% \mathrm{BSA}, 50 \mathrm{mM}$ Tris- $\mathrm{HCl}$, pH 8.2 for $20 \mathrm{~min}$ at RT, labeled with $20 \mathrm{~nm}$ gold conjugated goat anti-mouse IgG (Tebu-Bio, France) diluted $1 / 80$ in $1 \%$ BSA $50 \mathrm{mM}$ Tris- $\mathrm{HCl} \mathrm{pH}$ 8.2. They were successively washed once in $50 \mathrm{mM}$ Tris- $\mathrm{HCl} \mathrm{pH} 8.2$ and $\mathrm{pH} 7.4$ and in filtrated distilled water. Finally, immunocomplexes were fixed in glutaraldehyde $4 \%$, and negatively stain with Neutral Phosphotungstic Acid 1\%. Grids were observed on a transmission electron microscope (Jeol 
1400JEM, Tokyo, Japan) operating at $80 \mathrm{Kv}$ equiped with a camera Orius 1000 and digital Micrograph (CeCIL, Faculty of Medecine Laënnec, Lyon, France).

Lipid analysis. For total fatty acid profile of plasma and WAT, total lipids were extracted from $\sim 25 \mathrm{mg}$ of epididymal adipose tissue or $50 \mu \mathrm{L}$ of plasma using ethanol:chloroform 1:2 (v/v) (41). The organic phase was dried under $\mathrm{N}_{2}$ and total fatty acids were transmethylated using boron trifluoride in methanol (41). The FA methyl esters were then analysed by GC using a DELSI instrument model DI 200 equipped with a fused silica capillary SP-2380 column $(60 \times 0.22 \mathrm{~mm})(41)$. For estimation of the long-chain $n-3$ fatty acid status in phospholipids (PL) of adipose tissue, PL were separated from neutral lipids by Thin Layer Chromatography (TLC) using hexane 80 : diethylether 20 : acetic acid 1 (v/v/v). PL spot on silica gel was scrapped off and further transmethylated and analyzed by GC as described above.

Statistical analysis. All data are presented as means \pm SEM and were analysed with Statview 5.0 software (Abacus Concept, Berkeley). Results of the 5 groups were compared by analysis of variance (ANOVA) followed by posthoc test (Fisher PLSD). Simple comparisons were performed using Student's $t$-test. Differences were considered significant at the $P<0.05$ level. Principal component analysis was performed using JMP Software (version 9; SAS).

\section{RESULTS}

Lipid markers related to dietary fat composition in vivo. Considering the reported importance of FA composition in food on metabolic inflammation, we studied different oils in high fat diets (Table 1). The daily caloric intake of mice was similar among milk fat (MF), palm oil $(\mathrm{P})$, rapeseed oil $(\mathrm{R})$ and sunflower oil $(\mathrm{S})$ groups (data not shown). The body weight, the liver and the white adipose tissue (WAT) weights of the MF group were significantly higher 
than in mice of the other groups $(P<0.001$ or $P<0.05$, Table 2$)$; MF and R gained more weight than Ch. The profile of total FA in WAT (Table 2) reflected the composition of ingested dietary fats (Table 1). Arachidonic acid (20:4n-6), an n-6 FA precursor of proinflammatory derivatives in biological membranes, was similar in the phospholipids (PL) of WAT in all high-fat groups (Table 2). The global $n-6 / n-3$ ratio, reflecting increased risk of inflammation derived from PUFA metabolites, was lower in WAT-PL of R group than other high-fat groups (not different from Ch group), and higher in WAT-PL of S group. However, $n-6 / n-3$ ratio was not different in WAT-PL of MF, $\mathrm{P}$ and Ch groups. Moreover, palmitate content in plasma lipids was similar in $\mathrm{Ch}, \mathrm{MF}$ and $\mathrm{P}$ group on the one hand, and in $\mathrm{S}$ and $\mathrm{R}$ groups on the other hand (Table 2). Figure 1A shows that the plasma TAG concentration was higher in the MF group than in the $\mathrm{P}$ and $\mathrm{S}$ groups. Moreover, $\mathrm{P}, \mathrm{R}$ and $\mathrm{S}$ group presented lower plasma TAG than Ch group. However, plasma NEFA were similar among all groups (Figure 1B).

Markers of inflammation and of metabolic endotoxemia in plasma are modified by dietary fat composition. Regarding inflammation, the $\mathrm{P}$ diet led to a higher concentration in plasma of the inflammatory cytokine IL-6 than in other groups(Figure 2A). The P diet was also the only high fat diet to result in higher concentration in plasma of MCP-1 than Ch $(194.4 \pm 39.9 v s$ $101.4 \pm 40.1 \mathrm{pg} / \mathrm{mL} ; P<0.05)$. Overall, the $\mathrm{P}$ group was thus the only high-fat group to induce significantly higher inflammation in plasma than Ch group after 8 weeks $(P<0.05)$.

We then measured different circulating transporters and receptors in plasma that are involved in the pro-inflammatory potential of endotoxins, namely, LBP and sCD14. Among high-fat groups, only the $\mathrm{P}$ group presented higher LBP than $\mathrm{Ch}$ group $(P<0.01)$ (Figure $2 \mathrm{~B})$. LBP was also higher in $\mathrm{P}$ group than in other high-fat groups. Strikingly, in mice of the $\mathrm{P}$ group, plasma IL-6 levels were even highly correlated with plasma LBP levels $(P<0.003$, Figure 2C). The highest concentration of sCD14 was observed in the R group (Figure 2D) compared with MF, 
$\mathrm{P}$ and $\mathrm{S}$ groups $(P<0.05)$. Moreover, Figure $2 \mathrm{E}$ shows that the $\mathrm{P}$ group had the highest LBP/sCD14 ratio compared with all other groups including $\mathrm{Ch}(P<0.01)$; this $\mathrm{P}$ group also exhibited the greatest pro-inflammatory profile. This higher LBP/sCD14 ratio indicates a higher ability for plasma LPS to be vehicled to target tissues in the P group than in other groups. In contrast, MF, R, S and Ch groups presented both similar LBP/sCD14 ratios and similar IL-6 levels in plasma, lower than the P group.

Parallel to these differences in LPS transport ability, we also measured plasma endotoxemia by the LAL assay. As shown Figure 2F, mice fed the unsaturated FA diets tended to present a higher plasma endotoxemia than mice fed the saturated FA diets. The highest plasma endotoxemia measured by LAL assay was actually detected in the $\mathrm{R}$ group $(P<0.01$ vs $\mathrm{Ch}$, MF and $\mathrm{P}$ groups).

Markers of inflammation and endotoxin receptors in epididymal adipose tissue are modified by dietary fat composition. In WAT, expression of proinflammatory cytokine IL-1 $\beta$ that is produced both by adipocytes and macrophages was significantly higher in $\mathrm{P}$ group compared with all other groups $(P<0.05$, Figure 3A). Interestingly, expression of LPS-receptor CD14 was higher in the WAT of $\mathrm{P}$ group compared with all other groups including $\mathrm{Ch}(P<0.01)$ (Figure 3B). Moreover, the LPS receptor TLR4 was significantly enhanced in the WAT of P group in comparison with other groups as revealed both by Western Blotting (Figure 3C) and mRNA expression (Figure 3F). IL-6 that is expressed in macrophages was on the whole few expressed in WAT (Figure 3D). The global marker of macrophage infiltration CD68 tended to be more expressed in several high fat groups, namely P, R and S (Figure 3E).

These results show that the high-fat diet containing palm oil induced the highest amounts of inflammatory markers in plasma and highest expression of IL-1 $\beta$, TLR4 and CD14 in WAT. The milk-fat diet resulted in a lower inflammatory profile than the palm oil diet, while 
similarly rich in saturated FA but containing medium chain fatty acids (Table 1). Moreover, MF, R and S diets resulted in similar plasma levels of MCP-1, IL-6 and of IL-1 $\beta$, TLR4 and CD14 expression in WAT, not significantly different from Ch.

Altogether, the results suggest that mice fed a high-fat diet enriched with palm oil for 8 weeks presented a more active gut-derived endotoxin transport oriented towards inflammation than diets enriched with milk fat, rapeseed oil or sunflower oil. This could explain the higher circulating pro-inflammatory cytokine with the palm oil diet and higher WAT inflammation.

Endotoxemia could originate from LPS absorption from the gut microbiota in jejunum. In gut microbiota, total bacteria, Bacteroides/Prevotella C. leptum and Bl. coccoides groups did not appear to be modified by the quality of high fat diet considering the small sample size analyzed in this study. However, microbiota of the $\mathrm{P}$ group mice shows a E. coli population superior with regard to those of $\mathrm{MF}, \mathrm{R}$ and $\mathrm{S}$ groups (Figure 4). Furthermore, dietary fat composition seems to modify significantly the quantity of Lactobacillus/Leuconostoc group (dominant group in rodent microbiota) vs chow diet. In our study, Bifidobacterium genus and F. prausnitzii species were not detected in gut microbiota. Principal component analysis, based on the qPCR bacterial quantifications, was carried out and two first components (PC1 and PC2) plotted, represented $87.4 \%$ of whole inertia (insert Figure 4). It shows that the $E$. coli and Lactobacillus/Leuconostoc populations allow distinguishing the $\mathrm{Ch}$ and $\mathrm{P}$ diets of the others.

To test whether gut LPS could be partly absorbed by enterocytes, imaging was performed in the jejunum in high-fat fed mice. Electronic microscopy using an anti-LPS antibody revealed the presence of such LPS in enterocytes of the jejunal section, the major area of lipid absorption, regardless of the high fat group (Figure 5). 
Fatty acid structure modulates inflammatory markers in vitro on 3T3-L1 adipocytes. We studied the impact of myristic (14:0, present in milk fat), palmitic (16:0, present mostly in milk fat and palm oil), linoleic (18:2 $n$-6, present mostly in sunflower oil) and $\alpha$-linolenic (18:3 $n-3$, present mostly in rapeseed oil) acids, on MCP-1 and IL-6 secretion by 3T3-L1 cells. Stimulation with LPS increased MCP-1 secretion but no differences were observed between the different FA treatments (results not shown). Figure 6 shows that myristic and palmitic acids increased respectively 22.5 and 54.3 fold IL-6 accumulation in the culture media compared to the control $(P<0.05)$, while linoleic and linolenic acids had no effects. As expected, the addition of LPS was correlated with a significant accumulation of IL-6 in the culture medium for each FA (Figure 6). Some FA appeared to interact with LPS to induce a greater increase of IL-6 than LPS stimulation alone, such as palmitic and $\alpha$-linolenic acids. These data indicate that FA were able to participate in induced inflammation in adipocytes in vitro, either alone or synergistically with endotoxins.

\section{DISCUSSION}

The novel feature of the present study is that it focuses on the effects of dietary oil composition on LPS-related inflammation, an aspect that has thus far been widely ignored. This is an important issue for human nutrition because in Western diets, vegetable oils including palm oil are increasingly widely used conversely to animal fats such as milk fat (2, 19). FA can be divided into 4 groups: saturated FA, among which short and medium-chain and long-chain saturated FA (e.g. myristic, palmitic acids) can be distinguished; monounsaturated FA; $n-6$ polyunsaturated FA (e.g. linoleic acid) and n-3 polyunsaturated FA (e.g. linolenic acid). FA and their metabolites are known to act directly and indirectly to regulate metabolism. Among diet-induced metabolic diseases, obesity is characterized by 
low-grade inflammation and as recently revealed, by metabolic endotoxemia. Different works show a link between low-grade inflammation or related metabolic disorders and plasma endotoxemia or plasma $\operatorname{LBP}(9,18,25,43,64,69)$. However, to our knowledge, nothing was known to date about the importance of the composition of dietary fats and oils on such endotoxin-linked low-grade inflammation. The present data lead us to propose a relationship between the lipid composition of a high-fat diet and inflammation in connection with endotoxin receptors.

We first submitted mice to four different high-fat diets enriched with milk fat, palm oil, rapeseed oil and sunflower oil compared with regular chow. Then, we examined the role of major dietary FA on adipose tissue inflammation by using a model of adipose cells. The studied FA differed mainly by the number of carbons and unsaturations and the studied oils differed by their FA profile and by the position of FA on the triacylglycerol backbones (17, 51). Two hypotheses can be formulated: (i) the different FA can be transported and metabolized by different mechanisms leading to different inflammatory processes depending on their nature (long-chain saturated FA; $n-6$ vs n-3 FA) and/or (ii) the different dietary FA can induce some metabolic changes that will secondarily lead to changes in lipid and LPS absorption and transport, and ultimately contribute to inflammation.

Our results show that depending on oil composition in the diet, inflammation and endotoxin transporters were modulated differently. We showed in vitro that palmitic acid elicited the most important effect on IL-6 secretion by adipocytes, even if acute in vitro effects cannot reflect in vivo mechanisms. Moreover, we showed in vivo that the palm-oil enriched diet induced higher IL-6 than other diets including chow. This is consistent with epidemiological observations suggesting a positive association between diet and plasma IL-6 concentrations (5). Inflammation onset was not correlated with body weight gain. The $n-6$ FA are reported to be pro-inflammatory while $n-3$ FA are anti-inflammatory $(28,61)$. However in this study, the 
FA status in WAT-PL did not appear to contribute to plasma and WAT inflammation neither: indeed, no differences were observed for the percentage of arachidonic acid between the 4 groups and the ratio $n-6 / n-3$ FA was not correlated with the measured markers of circulating and WAT inflammation. Also, palmitate concentration in plasma was not correlated with inflammation as circulating palmitate was similar in $\mathrm{P}, \mathrm{MF}$ and $\mathrm{Ch}$ groups. Moreover, when LPS was added to FA in vitro, we observed the highest IL-6 production for palmitic and $\alpha$ linolenic acids. These results support the concept of a synergistic action of LPS and fatty acids on the secretion of pro-inflammatory cytokines.

We further investigated in vivo endotoxin metabolism depending on dietary oil composition. Indeed, pro-inflammatory LPS have been reported to be able to diffuse from the gut to the bloodstream during high fat diets, either by direct diffusion through intestinal paracellular permeability and/or through absorption by enterocytes during chylomicron secretion $(10,27$, 39). In this study, the presence of LPS inside jejunal enterocytes was indeed detected by electronic microscopy in all groups.

In this context, LBP and sCD14 appear to be key players in determining the inflammatory response to plasma LPS exposure. LBP and sCD14 are reported to function as molecules that shuttle LPS, having both activatory and suppressive effects via mCD14 activation and HDLmediated clearance, respectively $(35,70)$. Very recently, a higher LBP/sCD14 ratio has been observed in patients suffering from gut-derived inflammation compared with controls (37). LBP is actually increasingly used as a marker of metabolic endotoxemia in clinical and rodent studies $(43,53,56,64,69)$, because it is a major pro-inflammatory LPS transporter in plasma. In our study, the $\mathrm{P}$ group was the only group to present significantly higher LBP compared with $\mathrm{Ch}$ and higher than other high fat groups. Moreover, in P group, a strong correlation was observed between plasma LBP and plasma IL-6. Moreover, The P group was also the only 
one to present higher inflammation in plasma and IL-1 $\beta$, TLR4 and CD14 expression in WAT compared with Ch. Consistently, we highlight that mice of the $\mathrm{P}$ group also had a greater $\mathrm{LBP} / \mathrm{sCD} 14$ ratio than mice fed other diets. $\mathrm{LBP}$ is an acute-phase protein (72) whose plasma concentration increases during inflammation (23) and that delivers circulating LPS to CD14 or HDL (67). During an acute inflammatory response the LBP/sCD14 ratio is known to increase (67). Moreover, the binding of LPS to LBP-sCD14 conducts to the activation of proinflammatory cells via TLR4 pathway that result in production of pro-inflammatory markers including IL-6 and IL-1 $\beta$. The LPS thus induce a higher inflammatory reaction when bound to LBP than in free unbound form $(48,71)$. Moreover, we cannot rule out the possibility that LBP increase in P group was secondarily enhanced due to sensitivity to overall inflammatory status: IL-6 and IL-1 $\beta$ are indeed reported to induce the expression of LBP by airway epithelial cells (63) and IL-22 induces LBP in hepatocytes (78).

In turn, sCD14 recently appeared to provide protective effects against LPS response $(20,79)$. An excess of sCD14 in plasma is actually reported to buffer the inflammatory signals, avoiding LPS exposure with cell-anchored mCD14 (20). In mice, Fernandez-Real recently revealed that treatment with recombinant human sCD14 improves glucose tolerance following a high fat diet and decreases IL-1 $\beta$ expression in epididymal WAT (20). Similarly in the present study, high sCD14 in R group was associated with low IL-1 $\beta$ expression in WAT. In humans, the administration of sCD14 is now suggested as a therapeutic strategy to ameliorate phenotypes associated with the metabolic syndrome (20). Also, the increased ability of plasma to eliminate endotoxins by sCD14 after gastrointestinal surgery was reported to be more important than endotoxemia itself in patient clinical outcome; besides, sCD14 levels were beneficially increased by using a nutritional strategy in these patients to improve their clinical outcome (79). Altogether in our study using dietary lipid modifications, we observe 
that the lower inflammation of $\mathrm{R}$ group compared with $\mathrm{P}$ group is associated with significantly higher sCD14 in R group despite apparently elevated metabolic endotoxemia.

In our diets, plasma endotoxemia was not associated with fat content in the diet (22\% vs 3\%) but rather with lipid quality, plasma endotoxemia being on the whole higher in unsaturated $\mathrm{R}$ and $\mathrm{S}$ groups. In the literature, Amar et al. have shown that plasma endotoxemia was lower after control diet $(\sim 2 \mathrm{EU} / \mathrm{mL})$ compared with $35 \%$ fat $/ 37 \%$ carbohydrate $/ 28 \%$ protein diet $(\sim 3$ EU/mL) or high fat (72\%)/high protein $(28 \%)$ diet ( 6 EU/mL) (4). Cani et al. reported higher plasma endotoxemia in high-fat (in the range 5-10 EU/mL) vs chow diet $(<5 \mathrm{EU} / \mathrm{mL})(9,11$, 14). Importantly, these authors used high fat diets very different from the present study, i.e, up to $72 \%$ energy as fat and almost devoid of carbohydrates $(9,10,12,13)$. In contrast, our diets contained $38 \%$ energy as fat and the non-fat components were balanced using chow ingredients. The latter include wheat and barley that can contain non-digestible fermentable carbohydrates reported to be beneficial for the gut barrier and to lower endotoxemia (11). Because all our diets contained the same amount of such carbohydrates, our results suggest that oil composition in the diet may modulate their endotoxemia-lowering effects.

However, importantly, plasma endotoxemia is transient in nature with a reported half-life of LPS in plasma of only $<8$ minutes (49) because of LPS uptake by various receptors and transporters in plasma $(18,39)$. In sepsis, the severity of inflammatory reaction cannot be correlated to the blood levels of endotoxins (33). Indeed, endotoxins do not have to be necessarily detected in blood to confirm that endotoxins have been absorbed into blood, mainly because plasma endotoxemia fluctuates during the day and during digestion $(11,18$, 26, 39). Moreover, even using great caution such as sample heating, there are known difficulties in removing interference in blood regarding endotoxemia analysis (59). According 
to Sun et al. (69), the short half-life of LPS and the disadvantages associated with the LAL assay have limited its potential applications in routine clinical settings and large-scale studies. Therefore, the observed differences in plasma endotoxemia between the $\mathrm{R}$ group and other groups in this study may have been enhanced by a combination of (i) diurnal variations in detectable LPS concentrations, (ii) different digestion times at the moment of sacrifice and blood sampling. Indeed, mice were sacrificed in the fed state to be in the phase of intestinal lipid absorption where acute LPS absorption had been described (18, 27, 39). Conversely, having a relatively long half-life and reliable measurements, LBP might serve as a marker reflecting an "effective" LPS level and innate immune response triggered by LPS (69). As such, LBP is reported to be a marker better reflecting long-term exposure to endotoxins rather than plasma endoxemia itself $(18,33,60,69)$.

Altogether, our observation of different LBP/sCD14 ratios after different high fat diets is an indicator of specific metabolic adaptations to circulating endotoxin transport that can either efficiently trigger inflammation (high LBP in P group) or prevent inflammation (high sCD14 in $\mathrm{R}$ group). The different inflammation profiles between $\mathrm{R}$ and $\mathrm{P}$ groups may be due to the different impacts of these diets on the ability of plasma to bind endotoxins with a more important contribution of sCD14 compared with LBP for the R group. Importantly, elevated plasma levels of LBP have recently been reported to be associated with obesity, metabolic syndrome, type 2 diabetes and cardiovascular mortality in humans $(43,69)$. Therefore, our results support such a role of LBP in metabolic disorders, which could be modulated by the quality of dietary fats and oils.

Consistently with LBP plasma levels, we show that TLR4 and CD14 expression in epididymal adipose tissue were the highest following the palm-rich diet. This result suggests that WAT of the P group was more able to respond to circulating LPS by favouring the 
transduction of the inflammatory signal. It is important to note that (i) TLR4 and CD14 expression in WAT are modulated depending on oil composition of the diet and (ii) this profile of TLR4 and CD14 expression in WAT among the different groups is similar to the plasma IL-6 profile.

The observed difference in plasma IL-6 depending on the dietary oil composition can be explained by different mechanisms. Firstly, the ability of long-chain saturated FA to trigger inflammation via TLR4 was already shown in vitro $(16,66,68,74)$. Actually, TLR4 is known to be a potential candidate to initiate inflammation and insulin resistance via its activation by fatty acids $(3,40,66)$. In this study however, palmitic acid alone cannot explain differences in inflammation via TLR4 activation because plasma palmitate levels were not higher in $\mathrm{P}$ group compared with $\mathrm{Ch}$ and MF groups. Thus, evidence converges on the possibility that both FA and LPS can activate TLR4 and trigger inflammation in different tissues. Secondly, in vitro results show that differences in IL-6 release by adipose cells may be provoked by a synergistic action of LPS and FA. However, in vivo, differences of WAT inflammatory status were observed regarding IL-1 $\beta$ while IL-6 expression was modest, certainly because IL-6 is mostly expressed in macrophages that are diluted in WAT. Therefore, elevated plasma IL-6 in P group cannot be directly explained by IL-6 production by WAT. However, it may be due to an indirect effect of IL-1 $\beta$ that is secreted by WAT on the secretion of IL- 6 by the liver (47). Finally, we cannot rule out a possible contribution of gut microbiota on plasma inflammatory markers. Indeed, the literature shows that pro-inflammatory high-fat diets induce intestinal dysbiosis in C57B16/j mice, though with discrepancies such as decreased Bacteroides after 4 weeks (58) or increased Bacteroides after 12 weeks (62) using the same high fat diet containing $>60 \%$ of energy as lipids (mainly lard), caseins and starch. In other studies with $72 \%$ of energy as lipids (mainly lard), Bacteroides and Enterobacteriaceae did not vary after 4 weeks (9) while they decreased after 14 weeks (11). In this study with intermediate duration 
and lower fat intake using different fat sources, Bacteroides did not seem to vary. However $E$. coli tended to be higher in the dominant populations of gut microbiota in the few palm oil-fed mice analyzed. Because E. coli is reported to increase in the case of intestinal inflammation (45), it would be interested to investigate further whether high $E$. coli after high fat diet can contribute to metabolic inflammation. In this respect, we must note that the $\mathrm{Ch}$ diet, which is richer in carbohydrates and lower in fat, shows a significantly different gut microbiota profile compared with the high fat diets. Ch mice had higher numbers of lacobacilli and LPScontaining E. coli; moreover, the Bacteroidetes, E. coli and lactobacilli on the PCA scores plot track with the Ch diet. Because Ch contains more carbohydrates including non-digestible fermentable carbohydrates than high fat diets, this result highlights the importance of carbohydrate fermentation in regulating gut health and its subsequent implications for metabolic risk, in agreement with Cani et al. (11). Bifidobacteria have been reported to lower plasma endotoxemia and inflammation (11), however, this genus was undetectable in the presently studied mice. Altogether, considering the different reported effects of high fat diets on gut microbiota, we raise the question of whether not only the amount but also the biochemical composition and biological activity of gut-derived LPS would be modified by the diet; this should be the subject of further studies.

Importantly, lipid metabolism is now recognized to interact with endotoxemia. Apart from endotoxin receptors characterized in the present study, HDL are also reported to contribute to LPS clearance from plasma $(67,70)$. It would thus be interesting to conduct studies on interactions between plasma lipoprotein metabolism and LPS receptors after different high fat diets. Moreover, as discussed above, plasma endotoxemia varies according to the feeding status of mice and chylomicrons contribute to LPS transport in plasma. In the present study, plasma has been characterized in the fed state. In order to gain deeper knowledge of fasting 
and postprandial endotoxemia according to the diet, further studies should aim at measuring fasting and postprandial endotoxin metabolism after oil gavage following different high fat diets. Dose-response designs for the different high fat diets would also allow to conclude on the relative impact of fat composition and fat content on metabolic inflammation related to endotoxin receptors.

In humans, epidemiological and intervention studies often discuss that inflammation-related cardiovascular diseases would be positively related to consumption of SFA and negatively to consumption of PUFA $(1,7,15,65,77)$. However, recent data show that (i) substituting SFA with carbohydrates is unefficient or even deleterious regarding CVD risk $(50,54)$ so that the quality of fat (saturated FA vs PUFA) should be discussed on an isolipidic basis and (ii) SFA correspond to different individual molecular species including short and medium chain FA whose health effects should be considered independently $(42,50)$. Both the isolipidic design and existing differences in SFA chain length in saturated fats (MF, P) were accounted for in the present study. Noticeably, medium-chain triglycerides were shown to protect rats from LPS-induced injury of gut and liver, contrary to corn oil (36). Moreover, saturated fat structure can be very different among fats and oils, including FA position on the triglycerides $(51,55)$. In this respect, we must note that a greater inflammation was observed with the palm oil diet compared with the milk-fat diet. This indicates that low-grade inflammation induced by FA and endotoxin transport by LBP and SCD14 is not a common characteristic of all SFA but specific of each fat composition. Moreover, rapeseed oil, sunflower oil and milk fat were found to result in similar plasma levels of pro-inflammatory cytokine, despite their different FA and TAG structures, which was associated with similar LBP/sCD14 ratio. Importantly, rapeseed oil is rich in alpha-linolenic acid (ALA). This $n-3$ PUFA is described to present beneficial metabolic effects to prevent low-grade inflammation (61). The present results 
suggest a new beneficial effect of ALA-rich oils that can enhance plasma sCD14 and thus may buffer LPS and lower inflammatory response.

In conclusion, we demonstrate that compared with milk fat, rapeseed oil or sunflower oil, a high-fat diet formulated with palm oil results in higher inflammation in plasma and adipose tissue and a higher circulating $\mathrm{LBP} / \mathrm{SCD} 14$ ratio reflecting proinflammatory endotoxin transport. In contrast, rapeseed oil resulted in lower inflammation through higher levels of sCD14 despite elevated endotoxemia. Therefore, the onset of high-fat-diet induced inflammation in mice appears to depend on dietary fat composition, partly through plasma endotoxin receptors and transporters $\mathrm{sCD} 14$ and LBP oriented towards TLR4 and CD14 activation rather than being directly correlated with gut-derived plasma endotoxemia. Nutritional strategies can thus be envisaged by optimizing dietary lipid sources in order to blunt the metabolic path involving endotoxin transport that contributes to low-grade inflammation in metabolic diseases.

\section{Acknowledgements}

Anhydrous milk fat was kindly provided by Lactalis R\&D (Retiers, France). Refined nonhydrogenated palm oil was a kind gift of SIO (Saint Laurent Blangy, France). We greatly thank Laure Gabert and Corinne Louche-Pelissier (CRNH-RA) for their help in fatty acid analysis and Manar Awada for plasma NEFA measurements. Dominique Martel (SAFE) is acknowledged for his help regarding required diet quality. We thank Elisabeth Errazuriz for electronic microscopy. Pascale Plaisancié, David Patsouris and Julie-Anne Nazare are acknowledged for useful discussions.

FL and MCM designed research. FL, JLL, AG, CS, CS, PD, EL, JPF and MCM performed the experiments. FL, CD, JPF and MCM analyzed the data. FL, MCM and JPF wrote the 
manuscript. $\mathrm{NBH}, \mathrm{CD}, \mathrm{JB}, \mathrm{HV}$ and $\mathrm{NP}$ contributed to data interpretation and manuscript preparation. All authors read and approved the final manuscript.

\section{Grants}

Fabienne Laugerette acknowledges grants from INRA, SFN and Institut Benjamin Delessert. Marie-Caroline Michalski acknowledges a grant from ALFEDIAM-MSD. Laboratories are members of Institut Carnot LISA (Lipides pour l'Industrie et la SAnté), acknowledged for funding. The funders had no role in study design, data collection and analysis, decision to publish, or preparation of the manuscript.

\section{Disclosure}

The authors have no conflict of interest to declare.

\section{References}

1. Adkins $\mathbf{Y}$ and Kelley DS. Mechanisms underlying the cardioprotective effects of omega-3 polyunsaturated fatty acids. J Nutr Biochem 21: 781-792.

2. AFSSA. Etude Individuelle Nationale des Consommations Alimentaires 2 (INCA2). 2009.

3. Ajuwon KM and Spurlock ME. Palmitate activates the NF-kappa B transcription factor and induces IL-6 and TNF alpha expression in 3T3-L1 adipocytes. Journal of Nutrition 135: 1841-1846, 2005.

4. Amar J, Burcelin R, Ruidavets JB, Cani PD, Fauvel J, Alessi MC, Chamontin B, and Ferrieres J. Energy intake is associated with endotoxemia in apparently healthy men. Am J Clin Nutr 87: 1219-1223, 2008.

5. Baer DJ, Judd JT, Clevidence BA, and Tracy RP. Dietary fatty acids affect plasma markers of inflammation in healthy men fed controlled diets: a randomized crossover study. American Journal of Clinical Nutrition 79: 969-973, 2004.

6. Barbier de La Serre CB, Ellis CL, Lee J, Hartman AL, Rutledge JC, and Raybould HE. Propensity to high-fat diet-induced obesity in rats is associated with changes in the gut microbiota and gut inflammation. American Journal of Physiology-Gastrointestinal and Liver Physiology 299: G440-G448, 2010.

7. Borkman M, Storlien LH, Pan DA, Jenkins AB, Chisholm DJ, and Campbell LV. The Relation between Insulin Sensitivity and the Fatty-Acid Composition of Skeletal-Muscle Phospholipids. New England Journal of Medicine 328: 238-244, 1993.

8. Bradford MM. Rapid and Sensitive Method for Quantitation of Microgram Quantities of Protein Utilizing Principle of Protein-Dye Binding. Analytical Biochemistry 72: 248-254, 1976. 
9. Cani PD, Amar J, Iglesias MA, Poggi M, Knauf C, Bastelica D, Neyrinck AM, Fava F, Tuohy KM, Chabo C, Waget A, Delmee E, Cousin B, Sulpice T, Chamontin B, Ferrieres J, Tanti JF, Gibson GR, Casteilla L, Delzenne NM, Alessi MC, and Burcelin R. Metabolic endotoxemia initiates obesity and insulin resistance. Diabetes 56: 1761-1772, 2007.

10. Cani PD, Bibiloni R, Knauf C, Waget A, Neyrinck AM, Delzenne NM, and Burcelin R. Changes in gut microbiota control metabolic endotoxemia-induced inflammation in high-fat diet-induced obesity and diabetes in mice. Diabetes 57: 1470-1481, 2008.

11. Cani PD, Neyrinck AM, Fava F, Knauf C, Burcelin RG, Tuohy KM, Gibson GR, and Delzenne NM. Selective increases of bifidobacteria in gut microflora improve high-fatdiet-induced diabetes in mice through a mechanism associated with endotoxaemia. Diabetologia 50: 2374-2383, 2007.

12. Cani PD, Neyrinck AM, Tuohy KM, Fava F, Gibson GR, Knauf C, Burcelin RG, and Delzenne NM. Changes in gut microflora are responsible for high-fat diet-induced diabetes through a mechanism associated with endotoxaemia. Diabetologia 50: S68-S68, 2007.

13. Cani PD, Possemiers S, Van de Wiele T, Guiot Y, Everard A, Rottier O, Geurts L, Naslain D, Neyrinck A, Lambert DM, Muccioli GG, and Delzenne NM. Changes in gut microbiota control inflammation in obese mice through a mechanism involving GLP-2-driven improvement of gut permeability. Gut 58: 1091-1103, 2009.

14. Cani PD, Rottier O, Goiot Y, Neyrinck A, Geurts L, and Delzenne N. Changes in gut microbiota control intestinal permeability-induced inflammation in obese and diabetic mice through unexpected dependent mechanisms. Diabetologia 51: S34-S35, 2008.

15. Czernichow S, Thomas D, and Bruckert E. n-6 Fatty acids and cardiovascular health: a review of the evidence for dietary intake recommendations. Br J Nutr 104: 788-796.

16. Davis JE, Gabler NK, Walker-Daniels J, and Spurlock ME. Tlr-4 deficiency selectively protects against obesity induced by diets high in saturated fat. Obesity (Silver Spring) 16: 1248-1255, 2008.

17. Dubois V, Breton S, Linder M, Fanni J, and Parmentier M. Fatty acid profiles of 80 vegetable oils with regard to their nutritional potential. European Journal of Lipid Science and Technology 109: 710-732, 2007.

18. Erridge C, Attina T, Spickett CM, and Webb DJ. A high-fat meal induces lowgrade endotoxemia: evidence of a novel mechanism of postprandial inflammation. American Journal of Clinical Nutrition 86: 1286-1292, 2007.

19. FAPRI. US \& World Agricultural Outlook Database, 2009.

20. Fernandez-Real JM, Perez del Pulgar S, Luche E, Moreno-Navarrete JM, Waget A, Serino M, Sorianello E, Sanchez-Pla A, Pontaque FC, Vendrell J, Chacon MR, Ricart W, Burcelin R, and Zorzano A. CD14 modulates inflammation-driven insulin resistance. Diabetes 60: 2179-2186, 2011.

21. Furet J-P, Kong L-C, Tap J, Poitou C, Basdevant A, Bouillot J-L, Mariat D, Corthier Gr, Doré J, Henegar C, Rizkalla S, and Clément K. Differential adaptation of human gut microbiota to bariatric surgery-induced weight loss: links with metabolic and lowgrade inflammation markers. Diabetes 59: 3049-3057, 2010.

22. Furet JP, Firmesse O, Gourmelon M, Bridonneau C, Tap J, Mondot S, Dore J, and Corthier G. Comparative assessment of human and farm animal faecal microbiota using real-time quantitative PCR. Fems Microbiology Ecology 68: 351-362, 2009.

23. Gallay P, Barras C, Tobias PS, Calandra T, Glauser MP, and Heumann D. Lipopolysaccharide (Lps)-Binding Protein in Human Serum Determines the Tumor-NecrosisFactor Response of Monocytes to Lps. Journal of Infectious Diseases 170: 1319-1322, 1994. 
24. Geurts L, Lazarevic V, Derrien M, Everard A, Van Roye M, Knauf C, Valet P, Girard M, Muccioli GG, Francois P, de Vos WM, Schrenzel J, Delzenne NM, and Cani PD. Altered gut microbiota and endocannabinoid system tone in obese and diabetic leptinresistant mice: impact on apelin regulation in adipose tissue. Frontiers in Microbiology 2, 2011.

25. Ghanim H, Abuaysheh S, Sia CL, Korzeniewski K, Chaudhuri A, FernandezReal JM, and Dandona P. Increase in Plasma Endotoxin Concentrations and the Expression of Toll-like Receptors and Suppressor of Cytokine Signaling-3 in Mononuclear Cells After a High-Fat, High-Carbohydrate Meal Implications for insulin resistance. Diabetes Care 32: 2281-2287, 2009.

26. Ghanim H, Sia CL, Upadhyay M, Korzeniewski K, Viswanathan P, Abuaysheh S, Mohanty P, and Dandona P. Orange juice neutralizes the proinflammatory effect of a highfat, high-carbohydrate meal and prevents endotoxin increase and Toll-like receptor expression. American Journal of Clinical Nutrition 91: 940-949, 2010.

27. Ghoshal S, Witta J, Zhong J, de Villiers W, and Eckhardt E. Chylomicrons promote intestinal absorption of lipopolysaccharides. Journal of Lipid Research 50: 90-97, 2009.

28. Hagi A, Nakayama M, Shinzaki W, Haji S, and Ohyanagi H. Effects of the omega6:omega-3 fatty acid ratio of fat emulsions on the fatty acid composition in cell membranes and the anti-inflammatory action. JPEN J Parenter Enteral Nutr 34: 263-270, 2010.

29. Hailman E, Lichenstein HS, Wurfel MM, Miller DS, Johnson DA, Kelley M, Busse LA, Zukowski MM, and Wright SD. Lipopolysaccharide (LPS)-binding protein accelerates the binding of LPS to CD14. J Exp Med 179: 269-277, 1994.

30. Hiki N, Berger D, Dentener MA, Mimura Y, Buurman MA, Prigl C, Seidelmann M, Tsuji E, Kaminishi M, and Beger HG. Changes in endotoxin-binding proteins during major elective surgery: Important role for soluble CD14 in regulation of biological activity of systemic endotoxin. Clinical and Diagnostic Laboratory Immunology 6: 844-850, 1999.

31. Hildebrandt MA, Hoffmann C, Sherrill-Mix SA, Keilbaugh SA, Hamady M, Chen YY, Knight R, Ahima RS, Bushman F, and Wu GD. High-fat diet determines the composition of the murine gut microbiome independently of obesity. Gastroenterology 137: 1716-1724 e1711-1712, 2009.

32. Hotamisligil GS. Inflammation and metabolic disorders. Nature 444: 860-867, 2006.

33. Imai T, Shiga T, Saruki N, Nishikawa K, Fujita T, and Morishita Y. Change in plasma endotoxin titres and endotoxin neutralizing activity in the perioperative period. Can $J$ Anaesth 43: 812-819, 1996.

34. Kahn SE, Hull RL, and Utzschneider KM. Mechanisms linking obesity to insulin resistance and type 2 diabetes. Nature 444: 840-846, 2006.

35. Kitchens RL and Thompson PA. Modulatory effects of sCD14 and LBP on LPShost cell interactions. J Endotoxin Res 11: 225-229, 2005.

36. Kono H, Fujii H, Asakawa M, Yamamoto M, Matsuda M, Maki A, and Matsumoto Y. Protective effects of medium-chain triglycerides on the liver and gut in rats administered endotoxin. Annals of Surgery 237: 246-255, 2003.

37. Lakatos PL, Kiss LS, Palatka K, Altorjay I, Antal-Szalmas P, Palyu E, Udvardy M, Molnar T, Farkas K, Veres G, Harsfalvi J, Papp J, and Papp M. Serum Lipopolysaccharide-binding Protein and Soluble CD14 Are Markers of Disease Activity in Patients with Crohn's Disease. Inflammatory Bowel Diseases 17: 767-777, 2011.

38. Lamping N, Dettmer R, Schroder NW, Pfeil D, Hallatschek W, Burger R, and Schumann RR. LPS-binding protein protects mice from septic shock caused by LPS or gram-negative bacteria. J Clin Invest 101: 2065-2071, 1998. 
39. Laugerette F, Vors C, Geloen A, Chauvin MA, Soulage C, Lambert-Porcheron S, Peretti N, Alligier M, Burcelin R, Laville M, Vidal H, and Michalski MC. Emulsified lipids increase endotoxemia: possible role in early postprandial low-grade inflammation. Journal of Nutritional Biochemistry 22: 53-59, 2011.

40. Lee JY, Sohn KH, Rhee SH, and Hwang D. Saturated fatty acids, but not unsaturated fatty acids, induce the expression of cyclooxygenase- 2 mediated through Toll-like receptor 4. Journal of Biological Chemistry 276: 16683-16689, 2001.

41. Lefils-Lacourtablaise J, Chen P, Guichardant $\mathbf{M}$, Lagarde $\mathbf{M}$, and BernoudHubac N. Effects of polyunsaturated fatty acids n-3 on the secretion of adiponectin in the adipocyte cells 3T3-L1. Diabetes \& Metabolism 36: A94-A94, 2010.

42. Legrand P, Beauchamp E, Catheline D, Pedrono F, and Rioux V. Short chain saturated fatty acids decrease circulating cholesterol and increase tissue PUFA content in the rat. Lipids 45: 975-986.

43. Lepper PM, Kleber ME, Grammer TB, Hoffmann K, Dietz S, Winkelmann BR, Boehm BO, and Marz W. Lipopolysaccharide-binding protein (LBP) is associated with total and cardiovascular mortality in individuals with or without stable coronary artery disease Results from the Ludwigshafen Risk and Cardiovascular Health Study (LURIC). Atherosclerosis, 2011.

44. Ley RE, Backhed F, Turnbaugh P, Lozupone CA, Knight RD, and Gordon JI. Obesity alters gut microbial ecology. Proceedings of the National Academy of Sciences of the United States of America 102: 11070-11075, 2005.

45. Lupp C, Robertson ML, Wickham ME, Sekirov I, Champion OL, Gaynor EC, and Finlay BB. Host-mediated inflammation disrupts the intestinal microbiota and promotes the overgrowth of Enterobacteriaceae (Vol 2, pg 119, 2007). Cell Host \& Microbe 2: 204-204, 2007.

46. Lyons SR, Griffen AL, and Leys EJ. Quantitative real-time PCR for Porphyromonas gingivalis and total bacteria. Journal of Clinical Microbiology 38: 2362-2365, 2000.

47. Maachi M, Pieroni L, Bruckert E, Jardel C, Fellahi S, Hainque B, Capeau J, and Bastard JP. Systemic low-grade inflammation is related to both circulating and adipose tissue TNFalpha, leptin and IL-6 levels in obese women. Int J Obes Relat Metab Disord 28: 993-997, 2004.

48. Mathison JC, Tobias PS, Wolfson E, and Ulevitch RJ. Plasma Lipopolysaccharide (Lps)-Binding Protein - a Key Component in Macrophage Recognition of Gram-Negative Lps. Journal of Immunology 149: 200-206, 1992.

49. Matsushita H, Ohta S, Shiraishi H, Suzuki S, Arima K, Toda S, Tanaka H, Nagai H, Kimoto M, Inokuchi A, and Izuhara K. Endotoxin tolerance attenuates airway allergic inflammation in model mice by suppression of the T-cell stimulatory effect of dendritic cells. Int Immunol 22: 739-747, 2010.

50. Micha $\mathbf{R}$ and Mozaffarian D. Saturated fat and cardiometabolic risk factors, coronary heart disease, stroke, and diabetes: a fresh look at the evidence. Lipids 45: 893-905, 2010.

51. Michalski MC. Specific molecular and colloidal structures of milk fat affecting lipolysis, absorption and postprandial lipemia. Eur J Lipid Sci Technol 111, 2009.

52. Michalski MC, Soares AF, Lopez C, Leconte N, Briard V, and Geloen A. The supramolecular structure of milk fat influences plasma triacylglycerols and fatty acid profile in the rat. European Journal of Nutrition 45: 215-224, 2006.

53. Moreno-Navarrete JM, Manco M, Ibanez J, Garcia-Fuentes E, Ortega F, Gorostiaga E, Vendrell J, Izquierdo M, Martinez C, Nolfe G, Ricart W, Mingrone G, Tinahones F, and Fernandez-Real JM. Metabolic endotoxemia and saturated fat contribute 
to circulating NGAL concentrations in subjects with insulin resistance. Int J Obes (Lond) 34: 240-249.

54. Mozaffarian D. The great fat debate: taking the focus off of saturated fat. $J$ Am Diet Assoc 111: 665-666, 2011.

55. Mu H and Porsgaard T. The metabolism of structured triacylglycerols. Prog Lipid Res 44: 430-448, 2005.

56. Naito E, Yoshida Y, Makino K, Kounoshi Y, Kunihiro S, Takahashi R, Matsuzaki T, Miyazaki K, and Ishikawa F. Beneficial effect of oral administration of Lactobacillus casei strain Shirota on insulin resistance in diet-induced obesity mice. $J$ Appl Microbiol 110: 650-657.

57. Neels JG and Olefsky JM. Inflamed fat: what starts the fire? Journal of Clinical Investigation 116: 33-35, 2006.

58. Neyrinck AM, Possemiers S, Druart C, Van de Wiele T, De Backer F, Cani PD, Larondelle Y, and Delzenne NM. Prebiotic effects of wheat arabinoxylan related to the increase in bifidobacteria, Roseburia and Bacteroides/Prevotella in diet-induced obese mice. PLoS One 6: e20944, 2011.

59. Novitsky TJ. Limitations of the Limulus amebocyte lysate test in demonstrating circulating lipopolysaccharides. Ann N Y Acad Sci 851: 416-421, 1998.

60. Pastor Rojo O, Lopez San Roman A, Albeniz Arbizu E, de la Hera Martinez A, Ripoll Sevillano E, and Albillos Martinez A. Serum lipopolysaccharide-binding protein in endotoxemic patients with inflammatory bowel disease. Inflamm Bowel Dis 13: 269-277, 2007.

61. Poudyal H, Panchal SK, Diwan V, and Brown L. Omega-3 fatty acids and metabolic syndrome: Effects and emerging mechanisms of action. Prog Lipid Res 50: 372387, 2011.

62. Ravussin Y, Koren O, Spor A, Leduc C, Gutman R, Stombaugh J, Knight R, Ley RE, and Leibel RL. Responses of Gut Microbiota to Diet Composition and Weight Loss in Lean and Obese Mice. Obesity (Silver Spring), 2011.

63. Regueiro V, Campos MA, Morey P, Sauleda J, Agusti AG, Garmendia J, and Bengoechea JA. Lipopolysaccharide-binding protein and CD14 are increased in the bronchoalveolar lavage fluid of smokers. Eur Respir J 33: 273-281, 2009.

64. Ruiz AG, Casafont F, Crespo J, Cayon A, Mayorga M, Estebanez A, FernadezEscalante JC, and Pons-Romero F. Lipopolysaccharide-binding protein plasma levels and liver TNF-alpha gene expression in obese patients: evidence for the potential role of endotoxin in the pathogenesis of non-alcoholic steatohepatitis. Obes Surg 17: 1374-1380, 2007.

65. Sacks FM and Katan M. Randomized clinical trials on the effects of dietary fat and carbohydrate on plasma lipoproteins and cardiovascular disease. Am J Med 113 Suppl 9B: 13S-24S, 2002.

66. Shi H, Kokoeva MV, Inouye K, Tzameli I, Yin H, and Flier JS. TLR4 links innate immunity and fatty acid-induced insulin resistance. Journal of Clinical Investigation 116: 3015-3025, 2006.

67. Stoll LL, Denning GM, Li WG, Rice JB, Harrelson AL, Romig SA, Gunnlaugsson ST, Miller FJ, and Weintraub NL. Regulation of endotoxin-induced proinflammatory activation in human coronary artery cells: Expression of functional membrane-bound CD14 by human coronary artery smooth muscle cells. Journal of Immunology 173: 1336-1343, 2004.

68. Suganami T, Tanimoto-Koyama K, Nishida J, Itoh M, Yuan XM, Mizuarai S, Kotani H, Yamaoka S, Miyake K, Aoe S, Kamei Y, and Ogawa Y. Role of the Toll-like receptor 4/NF-kappa B pathway in saturated fatty acid-induced inflammatory changes in the 
interaction between adipocytes and macrophages. Arteriosclerosis Thrombosis and Vascular Biology 27: 84-91, 2007.

69. Sun L, Yu Z, Ye X, Zou S, Li H, Yu D, Wu H, Chen Y, Dore J, Clement K, Hu FB, and Lin X. A marker of endotoxemia is associated with obesity and related metabolic disorders in apparently healthy Chinese. Diabetes Care 33: 1925-1932, 2010.

70. Sussman M. Molecular medical microbiology. San Diego: Academic Press, 2002.

71. Tobias PS, Mathison J, Mintz D, Lee JD, Kravchenko V, Kato K, Pugin J, and Ulevitch RJ. Participation of Lipopolysaccharide-Binding Protein in LipopolysaccharideDependent Macrophage Activation. American Journal of Respiratory Cell and Molecular Biology 7: 239-245, 1992.

72. Tobias PS and Ulevitch RJ. Regulation by Acute Phase Proteins of Lps Binding to Lipoproteins. Eos-Rivista Di Immunologia Ed Immunofarmacologia 6: 68-70, 1986.

73. Trayhurn $\mathbf{P}$ and Beattie JH. Physiological role of adipose tissue: white adipose tissue as an endocrine and secretory organ. Proceedings of the Nutrition Society 60: 329-339, 2001.

74. Tsukumo DML, Carvalho MA, Carvalheira JBC, Prada PO, Hirabara SM, Schenka AA, Araujo EP, Vassallo J, Curi R, Velloso LA, and Saad MJA. Loss-offunction mutation in Toll-like receptor 4 prevents diet-induced obesity and insulin resistance. Diabetes 56: 1986-1998, 2007.

75. U.S. Department of Health and Human Services PHS, Food and Drug Administration. Guideline on Validation of the Limulus Amebocyte Lysate Test as an EndProduct Endotoxin Test for Human and Animal Parenteral Drugs, Biological Products, and Medical Devices, edited by FDA, 1987.

76. Warden CH and Fisler JS. Comparisons of diets used in animal models of high-fat feeding. Cell Metabolism 7: 277-277, 2008.

77. Warensjo E, Sundstrom J, Vessby B, Cederholm T, and Riserus U. Markers of dietary fat quality and fatty acid desaturation as predictors of total and cardiovascular mortality: a population-based prospective study. Am J Clin Nutr 88: 203-209, 2008.

78. Wolk K, Witte E, Hoffmann U, Doecke WD, Endesfelder S, Asadullah K, Sterry W, Volk HD, Wittig BM, and Sabat R. IL-22 induces lipopolysaccharide-binding protein in hepatocytes: a potential systemic role of IL-22 in Crohn's disease. J Immunol 178: 5973-5981, 2007.

79. Yao GX, Xue XB, Jiang ZM, Yang NF, and Wilmore DW. Effects of perioperative parenteral glutamine-dipeptide supplementation on plasma endotoxin level, plasma endotoxin inactivation capacity and clinical outcome. Clinical Nutrition 24: 510-515, 2005.

80. Zhang HS, DiBaise JK, Zuccolo A, Kudrna D, Braidotti M, Yu YS, Parameswaran P, Crowell MD, Wing R, Rittmann BE, and Krajmalnik-Brown R. Human gut microbiota in obesity and after gastric bypass. Proceedings of the National Academy of Sciences of the United States of America 106: 2365-2370, 2009. 


\section{Figure caption}
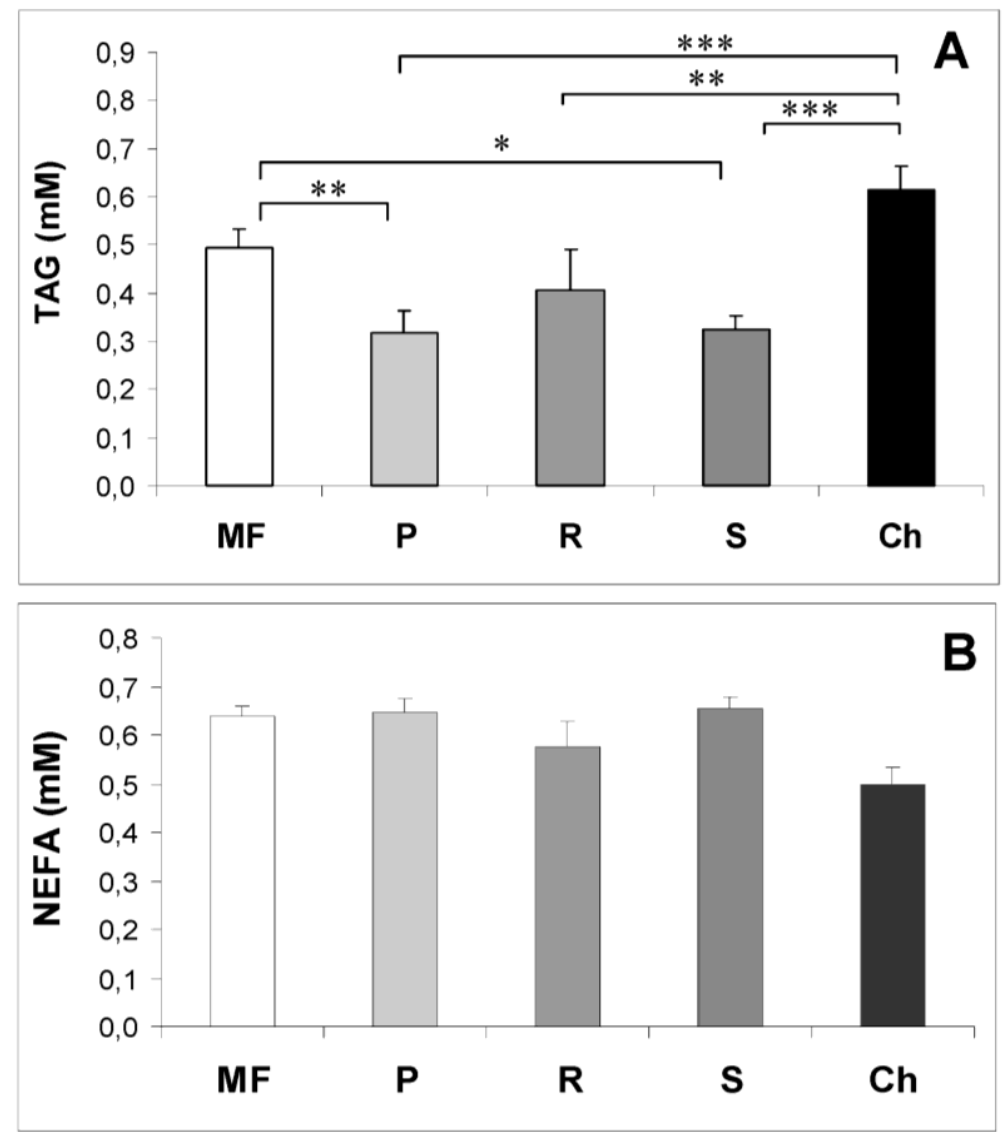

Figure 1: Plasma lipids in mice fed diet with milk fat $(\mathrm{MF})$, palm-oil $(\mathrm{P})$, rapeseed oil $(\mathrm{R})$ or sunflower oil (S) or normal low-fat chow (Ch). A: Plasma triglyceridemia (TAG, mM), B: plasma non-esterified fatty acids (NEFA, mM). Data are mean \pm SEM, $* P<0.05, * * P<0.01$, $* * * P<0.001 ; n=7$; ANOVA followed by Fisher test. 

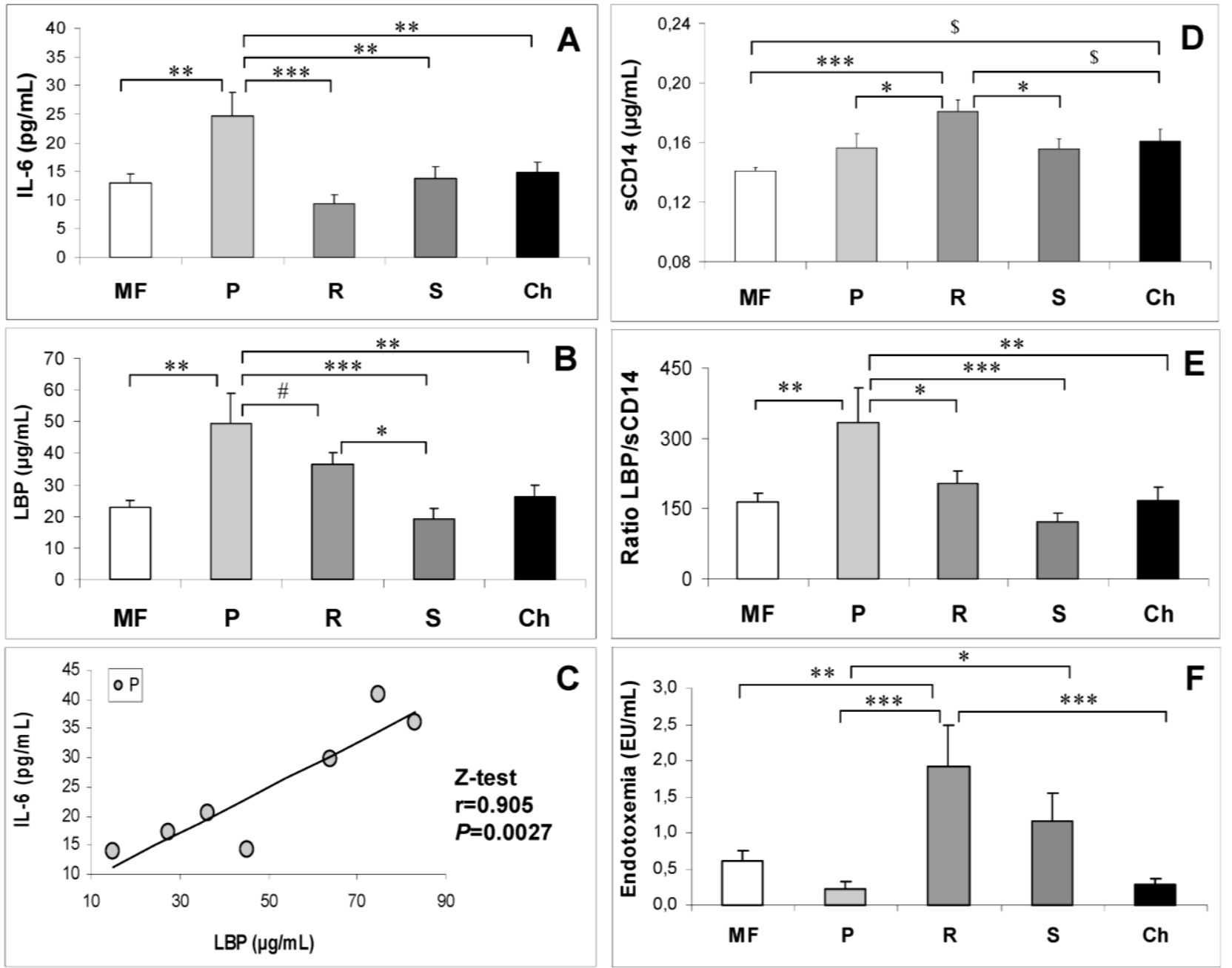

Figure 2: Inflammation and endotoxin metabolism parameters in plasma of mice fed diet with milk fat $(\mathrm{MF})$, palm-oil $(\mathrm{P})$, rapeseed oil $(\mathrm{R})$ or sunflower oil $(\mathrm{S})$ or normal low-fat chow (Ch). A: IL-6 (interleukin 6; pg/mL), B: LBP (lipopolysaccharide-binding protein; $\mu \mathrm{g} / \mathrm{mL}$ ), C: correlation IL-6 vs LBP for individual mice in P group, D: sCD14 (soluble cluster of differenciation $14 ; \mu \mathrm{g} / \mathrm{mL})$, E: ratio LBP/sCD14, F: Endotoxemia $(\mathrm{EU} / \mathrm{mL})$. Data are mean \pm SEM, $* P<0.05, * * P<0.01 ; * * * P<0.001 ;{ }^{*} \mathrm{P}=0.08,{ }^{\$} \mathrm{P}<0.06, n=7$, ANOVA followed by Fisher test. 

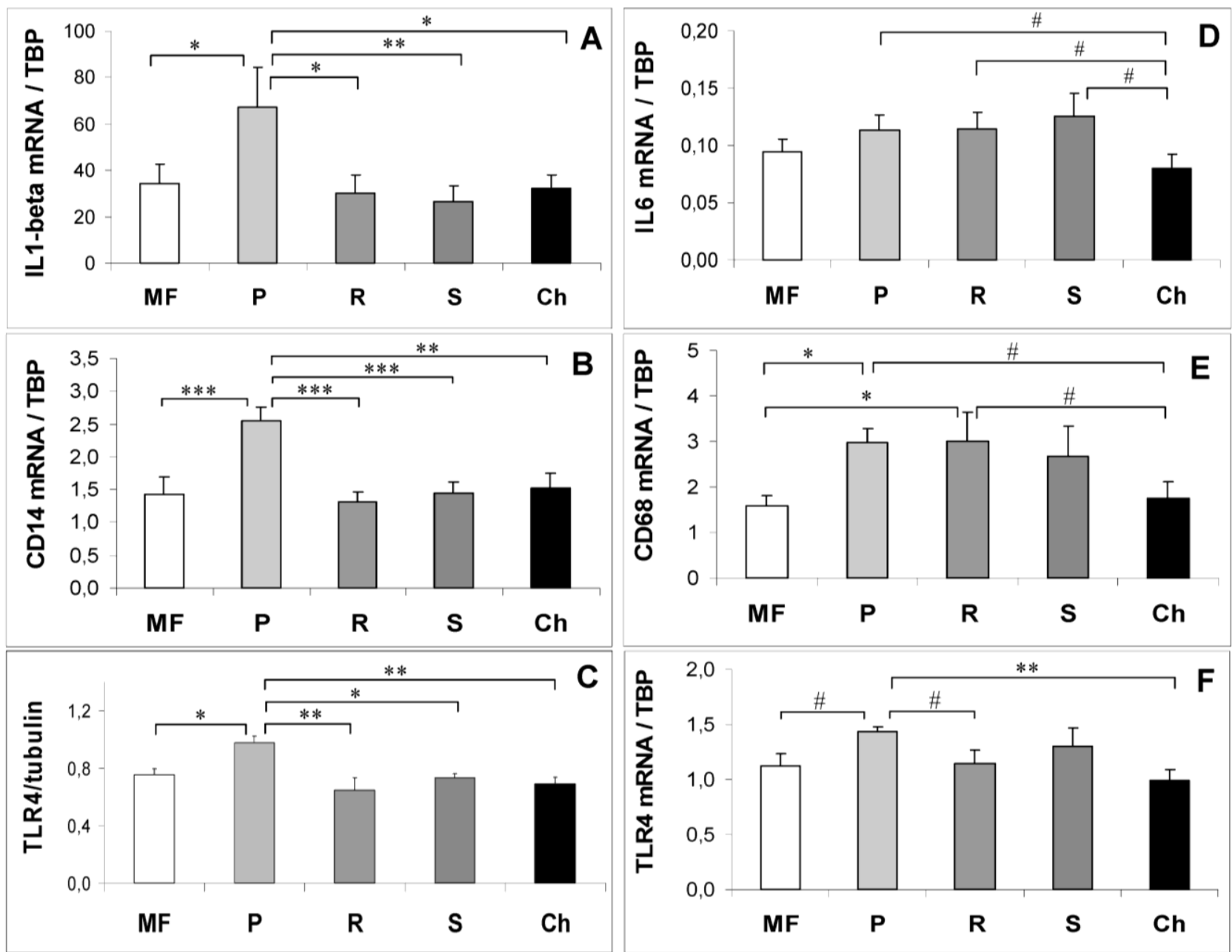

Figure 3. Inflammation and macrophage markers and endotoxin membrane receptors in WAT in mice fed diet with milk fat $(\mathrm{MF})$, palm-oil $(\mathrm{P})$, rapeseed oil $(\mathrm{R})$ or sunflower oil $(\mathrm{S})$ or normal low-fat chow (Ch): RT-qPCR results of mRNA expression (n=7). A: Interleukin-1beta (IL-1 $\beta$ ), B: CD14 (cluster of differentiation 14), C: Representative Western-Blot analysis of TLR4 (toll-like receptor 4)/Tubulin in WAT ( $n=4$ for densitometry analysis), D: interleukin 6 (IL-6), E: CD68 (cluster of differentiation 68), F: TLR4. Data are mean \pm SEM, $* P<0.05$, ${ }^{* *} P<0.01 ; * * * P<0.001 ;{ }^{\#} P<0.09$; ANOVA followed by Fisher test. 


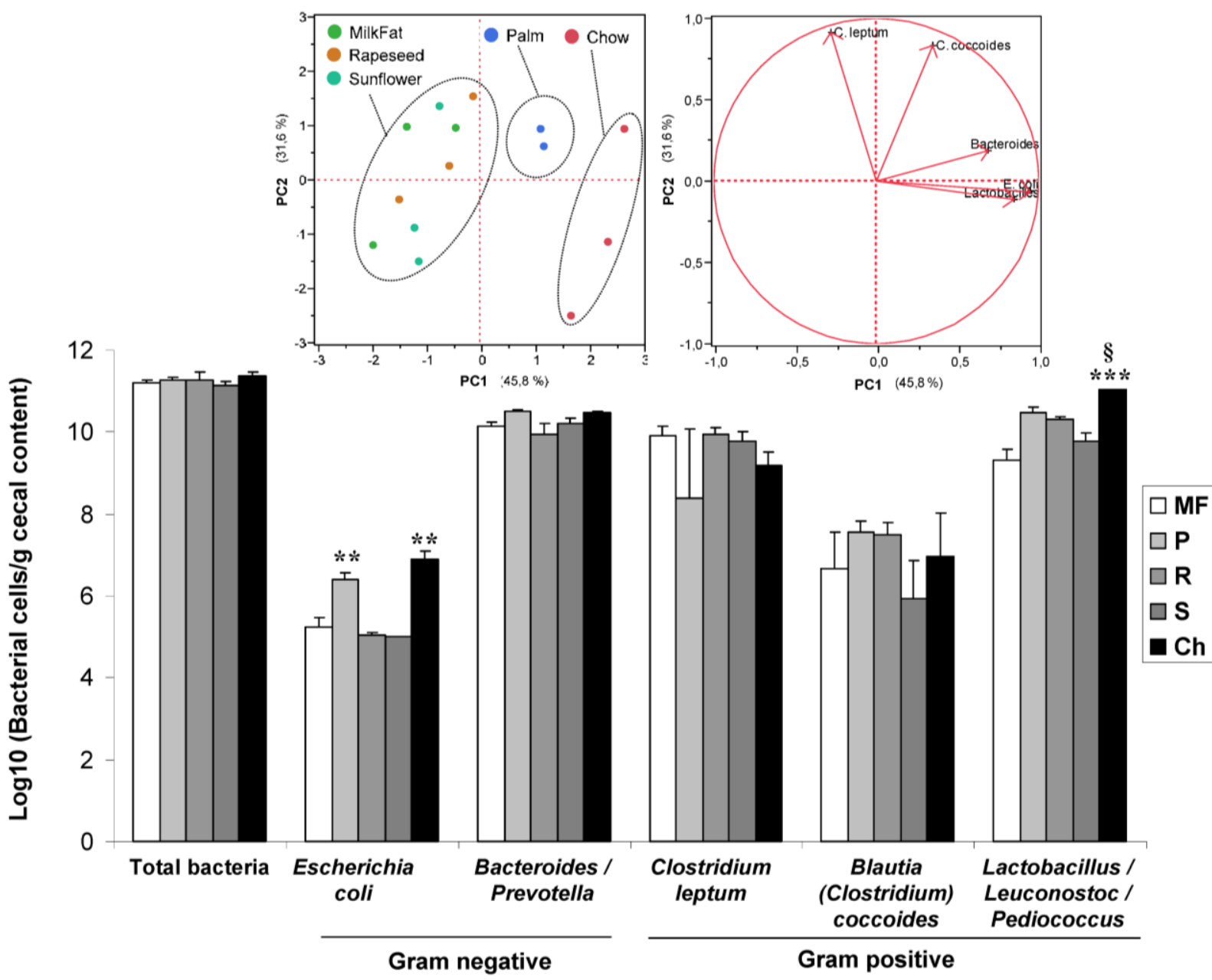

Figure 4: Groups of bacteria in caecal content of mice fed diet with milk fat (MF), palm-oil $(\mathrm{P})$, rapeseed oil $(\mathrm{R})$, sunflower oil $(\mathrm{S})$ or chow $(\mathrm{Ch})$. Bacterial numbers are expressed as $\log 10$ (bacterial cells per gram caecal content wet weight) \pm SEM, $n=3$. Legend highlights the lipopolysaccharide (LPS)-containing bacteria (Gram negative). Bifidobacteria and $F$. prausnitzii were measured but not detectable. Insert shows principal component analysis highlighting global differences among groups. $* * P<0.01$ vs $\mathrm{MF}, \mathrm{S}$ and $\mathrm{R} . * * * P<0.01$ vs $\mathrm{MF}$, $\mathrm{S}$ and R. ${ }^{\S} P<0.05$ vs P. Data were compared using Student's $t$-test. 

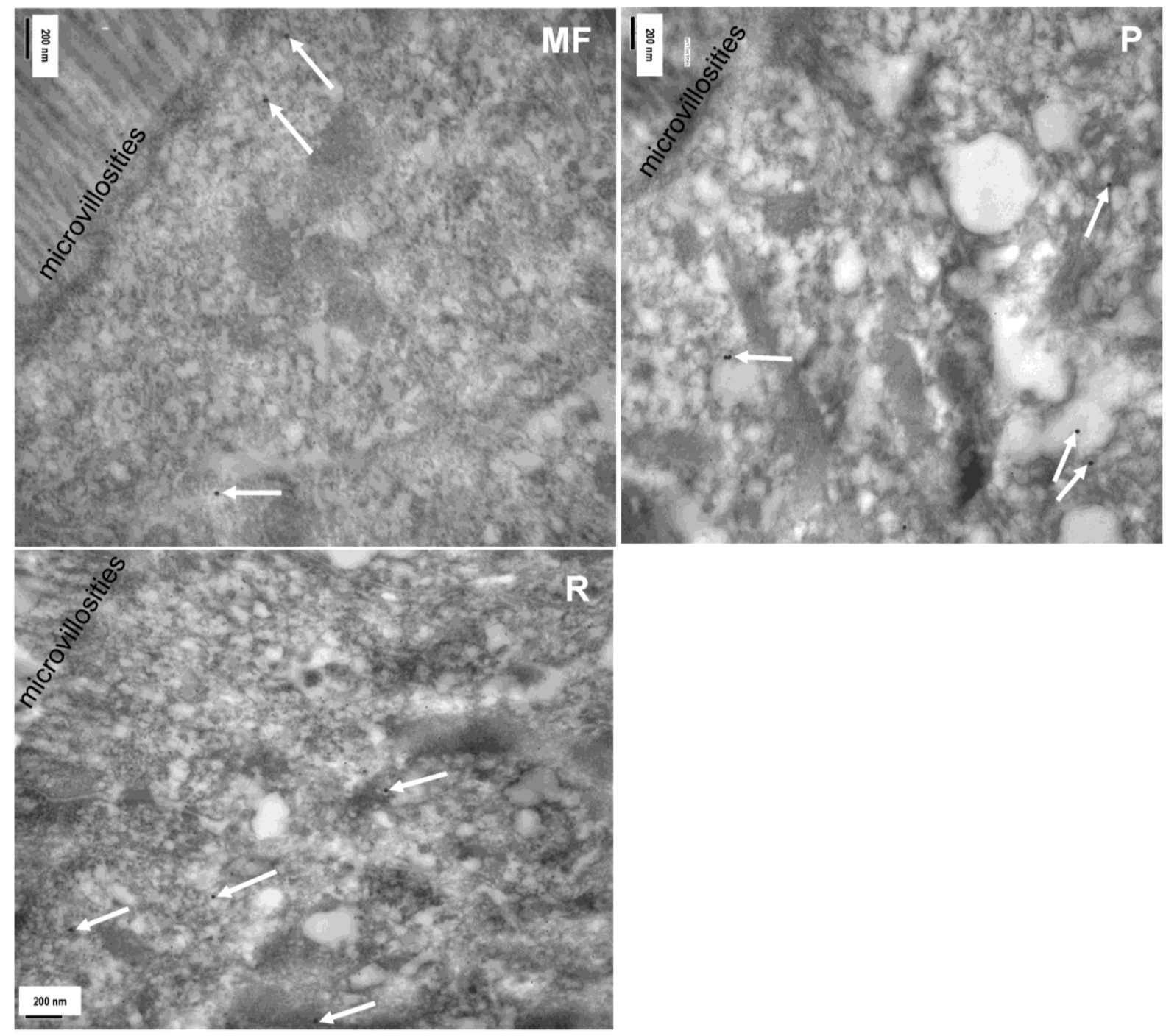

Figure 5: Electronic micrograph of a jejunal section of mice fed diet with milk fat (MF), palm-oil (P) or rapeseed oil (R) (point examples representative of images obtained on 40 enterocytes per group). White arrows show gold beads linked to E. coli-LPS. 


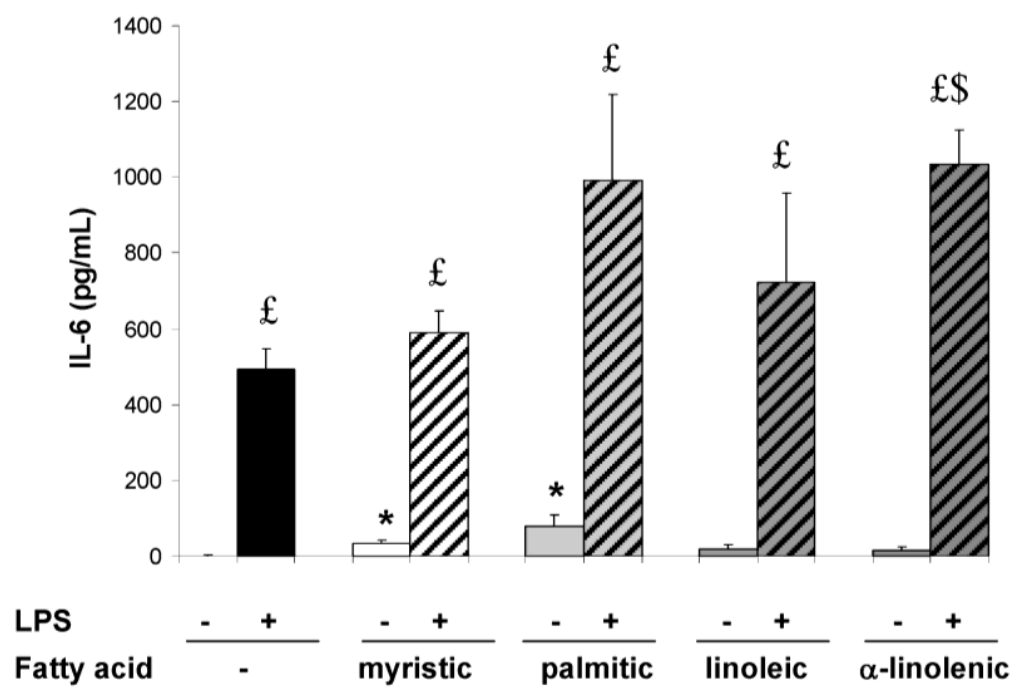

Figure 6: IL-6 (interleukin 6; pg/mL) in 3T3-L1 adipocytes treated for 24 hours with myristic acid (M), palmitic acid (P), linoleic acid (L), alpha-linolenic acid (Ln) or control medium (C). $* P<0.05, \mathrm{M} v s \mathrm{C}, \mathrm{L}, \mathrm{Ln}$ and $\mathrm{P} v s \mathrm{C}, \mathrm{L}, \mathrm{Ln} ;{ }^{\$} P<0.01 \mathrm{Ln}+\mathrm{LPS} v s \mathrm{C}+\mathrm{LPS},{ }^{£} P<0.001$ fatty acids $v s$ fatty acids + LPS. Data were compared using Student's t-test. Data are mean \pm SEM, $n=3$. 
Table 1. Diet composition.

\begin{tabular}{|c|c|c|c|c|c|}
\hline High fat based on: & Milk Fat & Palm & Rapeseed & Sunflower & Chow \\
\hline \multicolumn{6}{|l|}{ Ingredient $(\mathrm{g} / 100 \mathrm{~g})$} \\
\hline A04 SAFE & 80 & 80 & 80 & 80 & 100 \\
\hline Among which Protein & 12.8 & 12.8 & 12.8 & 12.8 & 16 \\
\hline Lipid & 2.4 & 2.4 & 2.4 & 2.4 & 3 \\
\hline $\mathrm{CH}^{*}$ & 37.6 & 37.6 & 37.6 & 37.6 & 47 \\
\hline \multicolumn{6}{|c|}{ Among which } \\
\hline Starch & 35.2 & 35.2 & 35.2 & 35.2 & 44 \\
\hline Sugars & 2.4 & 2.4 & 2.4 & 2.4 & 3 \\
\hline Cellulose & 3.2 & 3.2 & 3.2 & 3.2 & 4 \\
\hline Anhydrous milkfat & 20 & - & - & - & - \\
\hline Palm oil & - & 20 & - & - & - \\
\hline Rapeseed oil & - & - & 20 & - & - \\
\hline Sunflower oil & - & - & - & 20 & - \\
\hline Total lipids & 22.4 & 22.4 & 22.4 & 22.4 & 3 \\
\hline Energy (kcal/g) & 4.12 & 4.12 & 4.12 & 4.12 & 2.82 \\
\hline \multicolumn{6}{|l|}{ Energy $\%$} \\
\hline $\mathrm{CH}$ & 47.7 & 47.7 & 47.7 & 47.7 & 67.7 \\
\hline Protein & 12.6 & 12.6 & 12.6 & 12.6 & 22.7 \\
\hline Lipid & 37.7 & 37.7 & 37.7 & 37.7 & 9.6 \\
\hline \multicolumn{6}{|c|}{ FA mol/100 mol total FA in the diet } \\
\hline $10: 0$ & 0.5 & $\mathrm{Nd}$ & $\mathrm{Nd}$ & $\mathrm{Nd}$ & $\mathrm{Nd}$ \\
\hline $12: 0$ & 2.2 & $\operatorname{Tr}$ & $\mathrm{Nd}$ & $\mathrm{Nd}$ & $\mathrm{Nd}$ \\
\hline $14: 0$ & 12.1 & 0.5 & $\operatorname{Tr}$ & $\operatorname{Tr}$ & 0.5 \\
\hline $15: 0$ & 1.1 & $\operatorname{Tr}$ & $\mathrm{Nd}$ & $\mathrm{Nd}$ & $\operatorname{Tr}$ \\
\hline $16: 0$ & 32.3 & 45.0 & 6.6 & 6.8 & 17.0 \\
\hline $18: 0$ & 14.0 & 4.4 & 1.7 & 3.4 & 2.7 \\
\hline $18: 1 n-9$ cis & 29.0 & 36.6 & 58.5 & 42.9 & 20.3 \\
\hline $18: 2 n-6$ cis & 7.1 & 12.7 & 23.1 & 46.1 & 45.1 \\
\hline $18: 3 n-3$ & 1.2 & 0.5 & 9.7 & 0.4 & 3.5 \\
\hline $20: 4 n-6$ & $\operatorname{Tr}$ & $\operatorname{Tr}$ & $\operatorname{Tr}$ & $\operatorname{Tr}$ & 0.7 \\
\hline $20: 5 n-3$ & $\operatorname{Tr}$ & $\operatorname{Tr}$ & $\operatorname{Tr}$ & $\operatorname{Tr}$ & 0.8 \\
\hline $22: 6 n-3$ & $\operatorname{Tr}$ & $\operatorname{Tr}$ & $\operatorname{Tr}$ & $\operatorname{Tr}$ & 1.7 \\
\hline \multicolumn{6}{|l|}{ SFA } \\
\hline Subtotal 10:0-14:0 & 14.8 & 0.5 & $\mathrm{Nd}$ & $\mathrm{Nd}$ & 0.5 \\
\hline Total & 62.2 & 50.1 & 8.5 & 10.4 & 22.5 \\
\hline Ratio $n-6 / n-3$ FA & 4.8 & 21.1 & 2.4 & 91.4 & 7.0 \\
\hline
\end{tabular}

*Major sources of carbohydrates in this diet are non-processed cereals: wheat, corn, barley, wheat bran. Tr: trace $(<0.2 \%)$. Nd: non detected. 
Table 2. Morphologic parameters, profile of fatty acids of the epididymal white adipose tissue and plasma palmitate content in mice fed diet with milk fat (MF), palm-oil (P), rapeseed oil (R) or sunflower oil (S) or normal low-fat chow (Ch).

\begin{tabular}{|c|c|c|c|c|c|}
\hline & MF & $\mathrm{P}$ & $\mathrm{R}$ & $\mathrm{S}$ & $\mathrm{Ch}$ \\
\hline \multicolumn{6}{|l|}{$\begin{array}{l}\text { Morphologic } \\
\text { parameters: }\end{array}$} \\
\hline Initial Body weight (g) & $18.0 \pm 0.6$ & $18.1 \pm 0.6$ & $17.9 \pm 0.5$ & $18.0 \pm 0.3$ & $18.2 \pm 0.5$ \\
\hline Body weight gain (g) & $16.6 \pm 3.0$ & $9.8^{\$} \pm 0.9$ & $11.3^{\#, \mathfrak{E}} \pm 0.8$ & $9.8^{\$} \pm 1.6$ & $8.7^{\$} \pm 0.4$ \\
\hline $\begin{array}{l}\text { Food Intake } \\
(\mathrm{g} / \mathrm{mouse} / \mathrm{d})\end{array}$ & $4.73 \pm 0.23$ & $4.84 \pm 0.21$ & $6.12 \pm 0.48$ & $5.79 \pm 0.38$ & $4.74 \pm 0.29$ \\
\hline Liver weight(g) & $1.36 \pm 0.08$ & $1.04 \pm 0.04$ & $1.09 \pm 0.05$ & $1.12 \pm 0.07$ & $1.08 \pm 0.04$ \\
\hline WAT weight (g) & $1.23 \pm 0.23$ & $0.58^{\$} \pm 0.07$ & $0.69^{ \pm} \pm 0.06$ & $0.73^{\mathfrak{x}} \pm 0.07$ & $0.38^{\$} \pm 0.04$ \\
\hline \multicolumn{6}{|l|}{$\begin{array}{l}\text { Major FA in WAT } \\
\text { total FA } \\
\text { (mol/100 mol FA): }\end{array}$} \\
\hline $12: 0$ & $0.9 \pm 0.2$ & $\operatorname{Tr}$ & $\operatorname{Tr}$ & $\operatorname{Tr}$ & $\operatorname{Tr}$ \\
\hline $14: 0$ & $6.2 \pm 0.2$ & $1.1 \pm 0.0$ & $\operatorname{Tr}$ & $\operatorname{Tr}$ & $2.0 \pm 0.2$ \\
\hline $15: 0$ & $0.8 \pm 0.0$ & $\operatorname{Tr}$ & $\operatorname{Tr}$ & $\operatorname{Tr}$ & $\operatorname{Tr}$ \\
\hline $16: 0$ & $25.5^{\mathrm{a}} \pm 1.2$ & $29.3^{\mathrm{a}} \pm 0.9$ & $12.3^{\mathrm{b}} \pm 0.2$ & $13.3^{\mathrm{b}} \pm 0.3$ & $31.2^{\mathrm{a}} \pm 3.7$ \\
\hline $16: 1 n-7 \mathrm{t}$ & $8.1^{\mathrm{a}} \pm 0.4$ & $7.2^{\mathrm{a}} \pm 0.5$ & $0.9^{\mathrm{b}} \pm 0.5$ & $2.2^{\mathrm{b}} \pm 0.4$ & $11.1^{\mathrm{a}} \pm 1.2$ \\
\hline 18:0 & $4.8^{\mathrm{a}} \pm 0.3$ & $4.6^{\mathrm{a}} \pm 0.3$ & $2.2^{\mathrm{c}} \pm 0.7$ & $6.0^{\mathrm{b}} \pm 0.3$ & $6.1^{\mathrm{a}, \mathrm{b}} \pm 0.7$ \\
\hline $18: 1 n-9 \mathrm{c}$ & $37.5^{\mathrm{a}} \pm 1.7$ & $41.5^{\mathrm{a}} \pm 0.4$ & $55.0^{\mathrm{b}} \pm 1.6$ & $38.3^{\mathrm{a}} \pm 0.4$ & $23.2^{\mathrm{a}} \pm 6.3$ \\
\hline $18: 2 n-6 c$ & $8.2^{\mathrm{a}} \pm 0.6$ & $12.2^{\mathrm{a}} \pm 0.3$ & $21.7^{\mathrm{b}} \pm 0.9$ & $30.2^{\mathrm{c}} \pm 1.4$ & $18.2^{\mathrm{a}, \mathrm{b}} \pm 1.3$ \\
\hline $18: 3 n-3$ & $0.7^{\mathrm{a}} \pm 0.1$ & $0.3^{\mathrm{a}} \pm 0.0$ & $2.9^{\mathrm{b}} \pm 0.2$ & $0.3^{\mathrm{a}} \pm 0.0$ & $1.0^{\mathrm{a}} \pm 0.2$ \\
\hline $20: 4 n-6$ & $\operatorname{Tr}$ & $\operatorname{Tr}$ & $\operatorname{Tr}$ & $\operatorname{Tr}$ & $\operatorname{Tr}$ \\
\hline $20: 5 n-3$ & $\operatorname{Tr}$ & $\operatorname{Tr}$ & $\operatorname{Tr}$ & $\operatorname{Tr}$ & $\operatorname{Tr}$ \\
\hline $22: 6 n-3$ & $\operatorname{Tr}$ & $\operatorname{Tr}$ & $\operatorname{Tr}$ & $\operatorname{Tr}$ & $\operatorname{Tr}$ \\
\hline \multicolumn{6}{|l|}{$\begin{array}{l}\text { Status of WAT PL } \\
\text { in } n-6 / n-3 \text { FA: }\end{array}$} \\
\hline $\begin{array}{l}20: 4 n-6(\mathrm{~mol} / 100 \mathrm{~mol} \\
\text { FA in PL) }\end{array}$ & $3.0^{\mathrm{a}, \mathrm{b}} \pm 1.0$ & $2.9^{\mathrm{a}} \pm 0.4$ & $2.9^{\mathrm{a}, \mathrm{b}} \pm 1.0$ & $2.8^{\mathrm{a}, \mathrm{b}} \pm 0.5$ & $8.0^{\mathrm{b}} \pm 1.9$ \\
\hline $\begin{array}{l}22: 6 n-3(\mathrm{~mol} / 100 \mathrm{~mol} \\
\text { FA in PL) }\end{array}$ & $1.1^{\mathrm{a}} \pm 0.3$ & $0.9^{\mathrm{a}} \pm 0.1$ & $1.1^{\mathrm{a}} \pm 0.3$ & $0.6^{\mathrm{a}} \pm 0.1$ & $2.8^{\mathrm{a}} \pm 0.8$ \\
\hline$n-6 / n-3$ ratio & $13.9^{\mathrm{a}} \pm 2.2$ & $14.4^{\mathrm{a}} \pm 4.0$ & $3.3^{\mathrm{b}} \pm 1.2$ & $45.2^{\mathrm{c}} \pm 5.1$ & $6.6^{\mathrm{a}, \mathrm{b}} \pm 2.8$ \\
\hline $\begin{array}{l}\text { Palmitate in plasma } \\
\text { total FA } \\
(\mu \mathrm{g} 16: 0 / \mathrm{mL} \text { plasma })\end{array}$ & $227^{\mathrm{a}} \pm 32$ & $231^{\mathrm{a}} \pm 28$ & $144^{\mathrm{b}} \pm 15$ & $133^{\mathrm{b}} \pm 20$ & $220^{\mathrm{a}} \pm 19$ \\
\hline
\end{tabular}

For morphometric parameters, ${ }^{\$} P<0.001 \mathrm{MF} v s$ other groups, ${ }^{£} P<0.01 \mathrm{MF} v s$ other groups, ${ }^{\#} P<0.01 \mathrm{R}$ vs Ch. ANOVA followed by Fisher test. Data are mean \pm SEM for $n=8$ per group. ${ }^{\mathrm{a}, \mathrm{b}, \mathrm{c}}$ Means in a row that do not share a common letter are significantly different $(P<0.05), n=4$ per group for WAT-PL and $n=7$ per group for plasma palmitate, Tr: traces. 